\title{
The Evolution of Sentencing Policy and Practice in England and Wales, 2003-2015
}

\section{A B S T RAC T}

Sentencing in England and Wales has evolved in a direction apart from other common law countries. Although sentencing problems found in many Western nations are present, legislative and judicial responses have been very different. The use of custody rose steeply in the 1990s and has remained stable around that level in recent years. Crimes of violence and sexual aggression have, however, attracted increasingly longer sentences. The other principal changes are a steep increase in indeterminate sentence offenders, now accounting for some 19 percent of the prison population, and a striking rise in the volume of suspended sentences that has reduced the use of community sentences rather than terms of imprisonment. Net widening has therefore occurred. The principal distinction between England and most other jurisdictions is that statutorily binding guidelines now exist for both magistrates' and higher courts. Unlike most US guidelines that assign offenses to levels of seriousness within a single sentencing grid, the English guidelines are offense specific. The Sentencing Council has also issued "generic" guidelines applying to all categories of offending. The guidelines have been evolving for over a decade now and cover most common offenses. Growing,

Electronically published June 20, 2016

Julian V. Roberts is professor of criminology, University of Oxford. Andrew Ashworth is Vinerian Professor of English Law Emeritus, University of Oxford, and adjunct professor of law, University of Tasmania. The authors thank Keir Irwin Rogers for assistance in collecting statistics and the editor for very helpful comments on an earlier draft. Views expressed are solely those of the authors.

(C) 2016 by The University of Chicago. All rights reserved.

0192-3234/2016/0045-0001\$10.00 
but still limited, research suggests modest positive effects on consistency and proportionality in sentencing.

England may reasonably be regarded as the home of sentencing scholarship and research. The first sentencing text was published in the nineteenth century by an English magistrate (Cox 1877). Approximately a century later, the first influential modern sentencing texts appeared (Thomas 1970; Cross 1971). With respect to empirical research on sentencing, over a century ago the statistician Francis Galton published a remarkably prescient article in the journal Nature. Galton drew attention, for the first time, to the fact that certain custodial sentence lengths were used by judges very frequently, while others were seldom or never imposed. Galton argued that the natural human preference for particular numbers "interferes with the orderly distribution of punishment in conformity with penal deserts" (1895, p. 175). Galton's insight is remarkable because aside from discussion of the issue in the philosophical literature, no publication had clearly articulated the principle of desertbased, proportional sentencing, the first clear statement of penal desert being the seminal volume Doing Fustice almost a century later (von Hirsch 1976).

During the nineteenth century, numerous writers decried the lack of consistency and proportionality in sentencing (for a comprehensive discussion, see Radzinowicz and Hood [1979]). Thus one author wrote that "the mode of fixing the duration of penal restraints is from beginning to end little else than guessing. And how ill this system of guessing works we have abundant proofs. . . . Daily do there occur cases of extremely trifling transgressions visited with imprisonment of considerable length; and daily do there occur cases in which the penalty imposed is so inadequate that the offender, time after time commits new offenses" (Spencer 1860, p. 65). Crackenthorpe (1900, p. 194) noted that sentencing "discrepancies were still more startling when we turn from first sentences to those that follow after previous convictions. Some judges ignore such convictions altogether, others treat them as a ground for severely augmenting the subsequent sentence."

This concern over sentencing disparities led to calls for a more systematic approach to determining sentence. In fact, the earliest proposals for a sentencing commission, sentencing principles, and guidelines also emerged in England. A key development was the 1901 "Memorandum on Normal Punishments" prepared by Lord Alverstone on behalf of 
the judges of the King's Bench Division (see Radzinowicz and Hood 1979). This memorandum contained offense ranges or "normal sentences" for many common offenses. ${ }^{1}$ For example, for cases of indecent assault, the scheme proposed imprisonment for a period of between 1 and 12 months. Attempted murder in which life was endangered carried a range of penal servitude for a period of between 7 and 12 years (Report of the Advisory Council on the Penal System 1978, app. E).

Around the same time, a clear prototype guidelines system foreshadowing the current scheme was published in an article entitled "Can Sentences Be Standardised?" (Crackenthorpe 1900). Crackenthorpe proposed a sentencing table and guidelines system that would prescribe sentences for common crimes, based on judicial practice, and containing "starting points from which the judge would make his reckoning" (p. 114). The system would not involve "laying down hard-and-fast rules, for ... a large discretion would still be left to the judge who has to try the case" (p. 114). These specific proposals ultimately foundered, but approximately a century later, a system along these lines was finally implemented.

More recently, sentencing in England and Wales has evolved in a direction apart from almost all other common law countries. Although the problems of sentencing found in many Western nations-penal populism, a high rate of incarceration, and widespread public perceptions of leniency accompanied by criticism of the courts - are also present in England, the legislative and judicial responses have been different. ${ }^{2}$ The principal distinction between England and most other jurisdictions is that statutorily binding guidelines now exist for both magistrates and

\footnotetext{
${ }^{1}$ Ironically, in light of the volume of professional and public commentary on disparity, this memorandum begins with a defensive claim that "there is nothing in the sentences of Judges of the High Court of Justice which are recorded in the criminal statistics . . . to indicate the existence of any established difference of principle or of general practice in the sentences of Judges" (see Advisory Council on the Penal System 1978, p. 191).

${ }^{2}$ For the sake of brevity hereafter we usually use simply "England" to represent these two components of the United Kingdom. With the exception of the definitive sentencing guidelines and the Sentencing Council, most of the other sentencing provisions are also found in Scotland and Northern Ireland. A Scottish Sentencing Council was created in 2015, and it has a duty to prepare sentencing guidelines for the consideration of the High Court of Justiciary, Scotland's supreme criminal court, which may approve them in whole or in part, and with or without modifications (see https://www.scottishsentencingcouncil .org.uk). Sentencing guidelines of an advisory nature exist for Northern Ireland and may be found on the website of the Judicial Studies Board for Northern Ireland (see http:// www.jsbni.com/Publications/sentencing-guides-magistrates-court/Pages/default.aspx).
} 
higher courts. ${ }^{3}$ For this reason we pay particular attention to this innovation.

We explore developments in English sentencing over the period 200315. Our discussion begins with the passage of the Criminal Justice Act 2003, the most important sentencing statute of recent years. ${ }^{4}$ Our point of departure is an earlier review essay by Ashworth (2001). We address the following key questions:

- How has the relative use of different sanctions changed over the period, particularly the use of custody as a sanction?

- To what extent have statutory and nonstatutory influences contributed to these changes in sentencing practice?

- Has sentencing become more consistent, principled, parsimonious, or transparent?

- Is the use of imprisonment likely to increase or decline in the near future?

Section I of this essay provides background information on sentencing in England and Wales, noting the key role played by lay magistrates in the lower courts. We then summarize the principal empirical trends regarding prison admissions and sanctions imposed in the Crown Court and magistrates' courts over the past decade (2003-14). We note the relatively stable use of different punishments (often referred to here as "disposals") but also the dramatic increase in the use of the suspended sentence order since it was amended in 2005. Section II summarizes critical statutory and policy developments since the Criminal Justice Act 2003 and notes several reports that have called for a reduction in the use of custody as a sanction. Section III discusses the statutory authority that issues sentencing guidelines: the Sentencing Council for England

\footnotetext{
${ }^{3}$ South Korea now has a guideline scheme (http://www.scourt.go.kr/sc/engsc/index.jsp; Park 2010), and starting point sentences have been introduced in China (Roberts and Pei 2016). Guidelines have been developed but not adopted in New Zealand (Young and King 2013) and proposed (yet not developed) as part of sentencing reform in Israel (Roberts and Gazal-Ayal 2013). Other jurisdictions such as Uganda have developed advisory, judicially based guidelines (Kamuzze 2014), but England and Wales remains the only Western jurisdiction outside the United States to have instituted a detailed system of guidelines containing specific sentence ranges.

${ }^{4}$ For discussion of the evolution of sentencing policies prior to this legislation, see Ashworth (2001, 2010); for general information on sentencing in England and Wales, see Roberts (2015) and Ashworth and Roberts (2016).
} 
and Wales. We identify the principal differences between the composition, mandate, and duties of this body and analogous sentencing commissions in the United States. One important distinction is that the English council has no explicit mandate to modify its guidelines to respond to changes in the prison population. Instead, the council forecasts the impact of each new guideline on the number of prison places, and it is for another authority - the executive or the legislature - to correct any significant overcrowding in the prison population. This section of the essay also describes the nature and effects of the definitive sentencing guidelines, the first of which were issued in 2004 by a previous statutory body, the Sentencing Guidelines Council. Section IV draws some conclusions about the current state of sentencing in England and Wales.

\section{Sentencing Practices in England and Wales}

There are two levels of trial court in England and Wales: the Crown Court sits with judge and jury and adjudicates the more serious cases. Approximately two-thirds of Crown Court cases involve a guilty plea, and these are dealt with by judge alone-juries play no part in sentencing. ${ }^{5}$ However, most cases are sentenced in the magistrates' courts, where the arrangements are different. While in other common law jurisdictions sentencing is conducted by professional judges sitting alone or with a jury, the magistrates' courts in England and Wales are unique in relying largely on lay adjudicators and sentencers. ${ }^{6}$ The lay magistracy has existed for over six centuries, and there are currently approximately 26,000 sitting magistrates. They receive limited training on appointment and usually sit in benches of three, assisted by a legally qualified adviser. ${ }^{7}$ Some

\footnotetext{
${ }^{5}$ In a small number of US jurisdictions, juries play a role in felony sentencing, but the common law norm is for sentencing by professional judges.

${ }^{6}$ A number of jurisdictions such as Germany and Italy use hybrid tribunals composed of professional judges and members of the public, and some countries use lay justices for certain decisions such as bail; but England is alone in using lay magistrates to both hear trials and sentence offenders.

${ }^{7}$ Legal advisors play a critical yet rather hidden role in shaping sentencing in the magistrates' courts. For example, they generally provide the little ongoing training offered magistrates. In addition, they may offer advice that affects the sentence imposed. Anecdotal evidence suggests that legal advisors sometimes advise that some cases in which immediate custody seems likely may receive a suspended sentence order (SSO). This may help explain the striking rise in the use of SSOs that we document in this essay. Very little research has explored their influence on sentencing patterns, and documenting their role remains a research priority.
} 
magistrates' courts, particularly in large cities, have a professional district judge who sits alone. ${ }^{8}$

The maximum sentence that may be imposed in a magistrates' court is 6 months' imprisonment or a total of 12 months' imprisonment if there are two or more convictions. The importance of the magistrates' courts is signaled by the fact that in 2014, fully 93 percent of all offenders sentenced were sentenced at that level (Ministry of Justice 2015c). All cases begin in a magistrates' court, which, if it believes that its own sentencing powers are inadequate, may decline jurisdiction and commit the case to the Crown Court for sentencing. ${ }^{9}$ Appeals against sentences in the magistrates' courts are heard in the Crown Court; appeals from the Crown Court are heard by the Court of Appeal (Criminal Division).

Another unique characteristic of English sentencing is the more modest role of the prosecutor. Although specific and robust sentencing submissions from both parties are the norm in common law countries, English prosecutors generally limit themselves to highlighting the important aggravating circumstances and providing information that may be useful to the court at sentencing including any relevant guidelines or guideline cases. ${ }^{10}$ This more circumscribed prosecutorial role is slowly changing. Prosecutors now address the guidelines category they believe is appropriate to the case at bar, although they stop short of routinely recommending specific sentences, which is common practice in North American jurisdictions.

\section{A. Recent Prison Population and Sentencing Trends}

The picture of sentencing trends emerging from the last 10 years changes depending on the specific indicator of severity employed or

\footnotetext{
${ }^{8}$ The magistrates' court statistics do not provide a breakdown indicating the percentage of cases sentenced by the district judges rather than panels of lay magistrates, but given the number of the former, it is likely that lay magistrates are responsible for the vast majority of decisions.

${ }^{9}$ The divided jurisdiction has been the subject of much commentary and research. Over the years, the government has contemplated both increasing the powers of the magistrates and also reducing their jurisdiction through the greater use of district judges. One recurrent observation is that magistrates not infrequently decline jurisdiction and transfer a case to the Crown Court, only for the offender to ultimately receive a sentence well within the magistrates' sentencing powers.

${ }^{10}$ See the Criminal Procedure Rules, Rule 37.10(3) available at http://www.cps.gov.uk /legal/s_to_u/sentencing_-_general_principles/\#a01.
} 
the level of court. ${ }^{11}$ Our general conclusion is that England has experienced a period of relative stability with respect to sentence severity measured by the immediate custodial rate, although this generalization is subject to several important qualifications, particularly with respect to sentence lengths and the number of indeterminate sentences. The principal trends over the past decade include the following:

- The prison population has been reasonably stable in recent years, around the level achieved after its sharp rise in the previous decade.

- The number of sentenced cases has declined significantly at both levels of court.

- The rate of cases sent to immediate custody or given a fine has been stable.

- The rate of suspended sentence orders (SSOs) has increased significantly, yet most of these orders appear to have replaced community sentences rather than custodial sentences, leading to considerable net widening and no significant reduction in the use of immediate custody.

- The rate of community orders imposed in indictable cases has declined significantly in the Crown Court.

- The average custodial sentence length has increased, particularly for violent and sexual offenses.

\section{B. Prison Population Trends ${ }^{12}$}

Between 1993 and 2015, the prison population almost doubled, rising from to 44,200 to 86,000 (Ministry of Justice 2015b). Over the more recent period covered in this essay (2003-15), the increase has been less steep. The principal causes of the increase over the 20 -year period were harsher sentencing, including higher custody rates and longer prison sentences; tougher enforcement outcomes for community penalties and prisoners released on license; and a more serious mix of offenses

\footnotetext{
${ }^{11}$ For earlier discussion and data relating to sentencing and the prison population, see Hough, Jacobson, and Millie (2003) and Ministry of Justice (2013).

${ }^{12}$ The focus of this essay is on sentenced admissions to prison rather than the total prison population, including remand prisoners. For information on the remand population, see Player et al. (2010).
} 
appearing for sentencing (Ministry of Justice 2013). ${ }^{13}$ As of November 2015 , the population count was 85,982 , approximately the same as a year earlier $(85,902)$. A further 2,111 prisoners were serving home detention curfews (Ministry of Justice 2015c).

Overall, prisons were functioning as of August 2014 at 112 percent of Certified Normal Accommodation (CNA). This masks considerable variability: a significant number of institutions are substantially overpopulated. For example, in August 2014, Wandsworth prison in London housed 1,578 prisoners against a CNA of 843, an overpopulation of 167 percent (Ministry of Justice 2015c, p. 3). In fully two-thirds of prisons, the number of prisoners exceeds the CNA. Some of these prisoners are held in overcrowded conditions, with two prisoners in a cell constructed for one.

\section{Sentencing Trends}

Across all courts in 2014, a total of 1,215,695 cases were sentenced, a drop of 21 percent from the peak in 2004 (table 1). The decline in caseload reflects the fall in recorded crime rates over this period and to a lesser degree increased use of "out-of-court" disposals. A different pattern emerges for the two levels of court: over the decade there was a 26 percent decline in cases sentenced in the magistrates' courts yet a 13 percent increase in cases sentenced in the Crown Court. The volume of cases has continued to decline in the magistrates' courts and for the past 2 years has now been dropping in the Crown Court, where the number sentenced fell by 16 percent between 2011 and 2013 .

Table 1 reveals that the proportionate use of different disposals has changed little over the last decade - at least when all cases (indictable and summary) sentenced in all courts are considered. Although the volume of all disposals (except the SSO) has declined (to reflect the drop in cases sentenced), the courts are using the principal sanctions in relatively constant proportions over the years. Fines, for example, were imposed in 70 percent of cases in 2014 , the same percentage as a decade earlier. The proportionate use of immediate custody was also invariable, accounting for 7 or 8 percent of all cases over the period 2003-14. The rate of community orders declined (from 13 percent in 2003 to 9 percent in 2014)

\footnotetext{
${ }^{13}$ And in this order: the Ministry of Justice (2013) report ascribes fully 85 percent of the increase in the prison population over the 20 -year period to changes in the rate and length of immediate custodial sentences.
} 


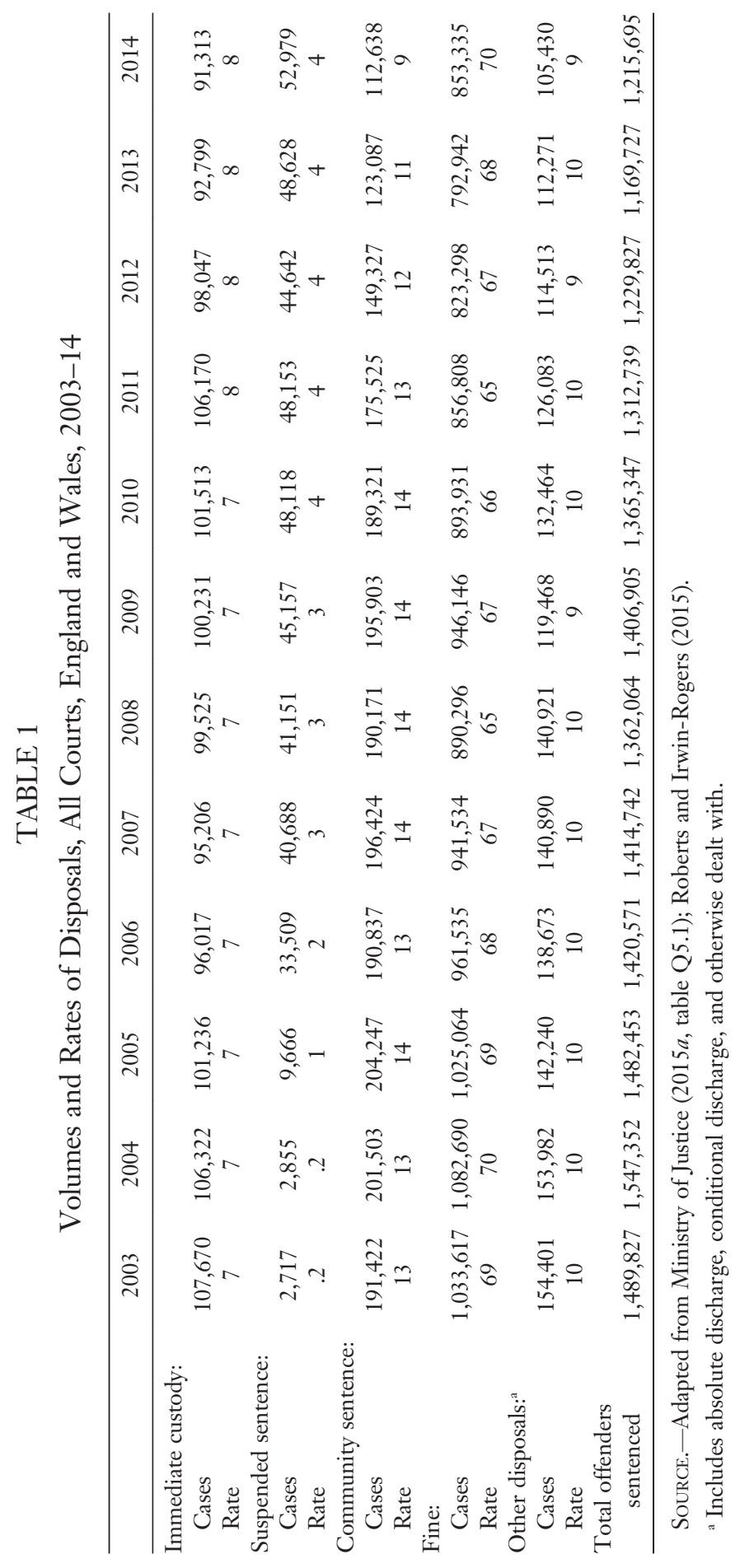

This content downloaded from 134.084.001.170 on June 25, 2016 03:24:58 AM

All use subject to University of Chicago Press Terms and Conditions (http://www.journals.uchicago.edu/t-and-c). 
but much more markedly when we consider indictable cases (see below). Figure 1 graphs the use of the principal disposals for indictable cases in all courts over the period 1999-2014. ${ }^{14}$ Figure 2 presents the use of immediate custody over the same period for both levels of court.

Variation emerges when trends in the two levels of court are compared. In the Crown Court, the proportion of sentences involving immediate custody declined from 63 percent of all indictable cases in 1999 to 56 percent in 2014 and remained stable in the magistrates' court at 4 or 5 percent over the entire decade. This pattern of penal stability must now be qualified by noting some important shifts in practice.

\section{Decline of Community Orders and Increase in Suspended Sentence Orders}

One theme noted in the previous review was the revival of community disposals (Ashworth 2001, pp. 67-72). Ashworth reported that community sentences accounted for 24 percent of sentences for indictable offenses in 1996, up from 14 percent a decade earlier. This trend has now reversed itself. As can be seen in table 2, the rate of community sentences for indictable offenses in all courts has declined from a peak of 37 percent in 2005 to 21 percent in 2014. The fall has been particularly striking in the Crown Court: in 2004, 30 percent of disposals in indictable cases involved a community penalty; by 2014 this had fallen to 12 percent (table 3 ). Where have these cases gone? The answer lies in the increased use of the suspended sentence of imprisonment.

The decade witnessed a dramatic rise in the use of the SSO, principally in the Crown Court. Although the SSO has been available to courts since 1967 (Criminal Justice Act 1967, sec. 39; see Ashworth [2015] for discussion), the disposal was reinvigorated when the Criminal Justice Act 2003 removed the restriction that this form of custody be imposed only in exceptional circumstances. ${ }^{15}$ The anticipated consequence was an increase in the volume of SSOs, and so it has proved. Suspended sentence orders accounted for only 2 percent of Crown Court cases in 2004 but fully 27 percent in 2014 (table 3). The English experience is at odds

\footnotetext{
${ }^{14}$ The category of "indictable cases" includes all serious cases and excludes summary offenses. Many indictable cases for offenses such as theft and aggravated assaults are dealt with by the magistrates' courts.

${ }^{15}$ The SSO has since been further amended by the Legal Aid, Sentencing and Punishment of Offenders Act 2012. As a result of these amendments, sentences of imprisonment of up to 2 years may now be suspended, a reform that may increase still further the number of suspended sentences imposed.
} 


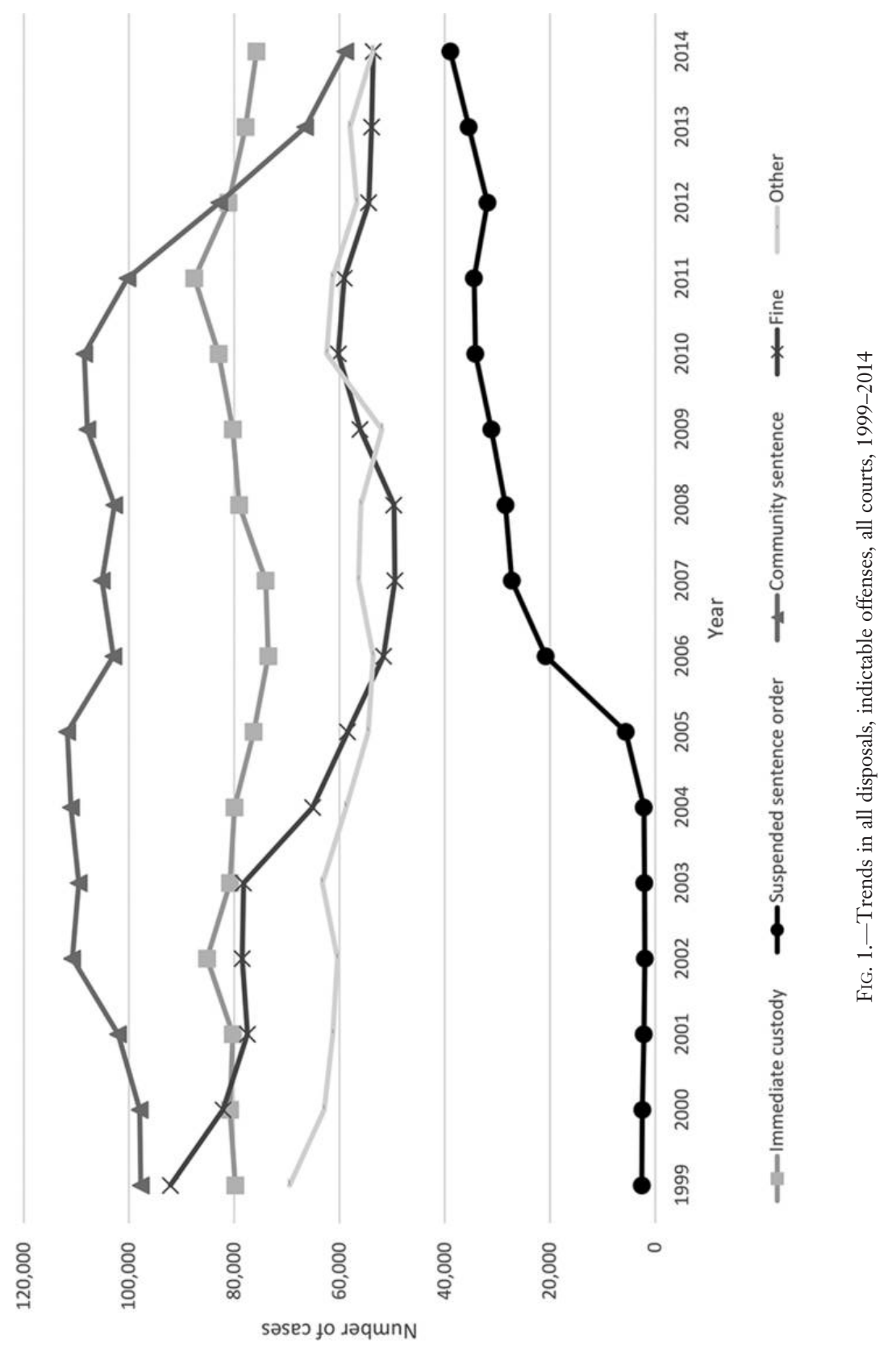

This content downloaded from 134.084.001.170 on June 25, 2016 03:24:58 AM 


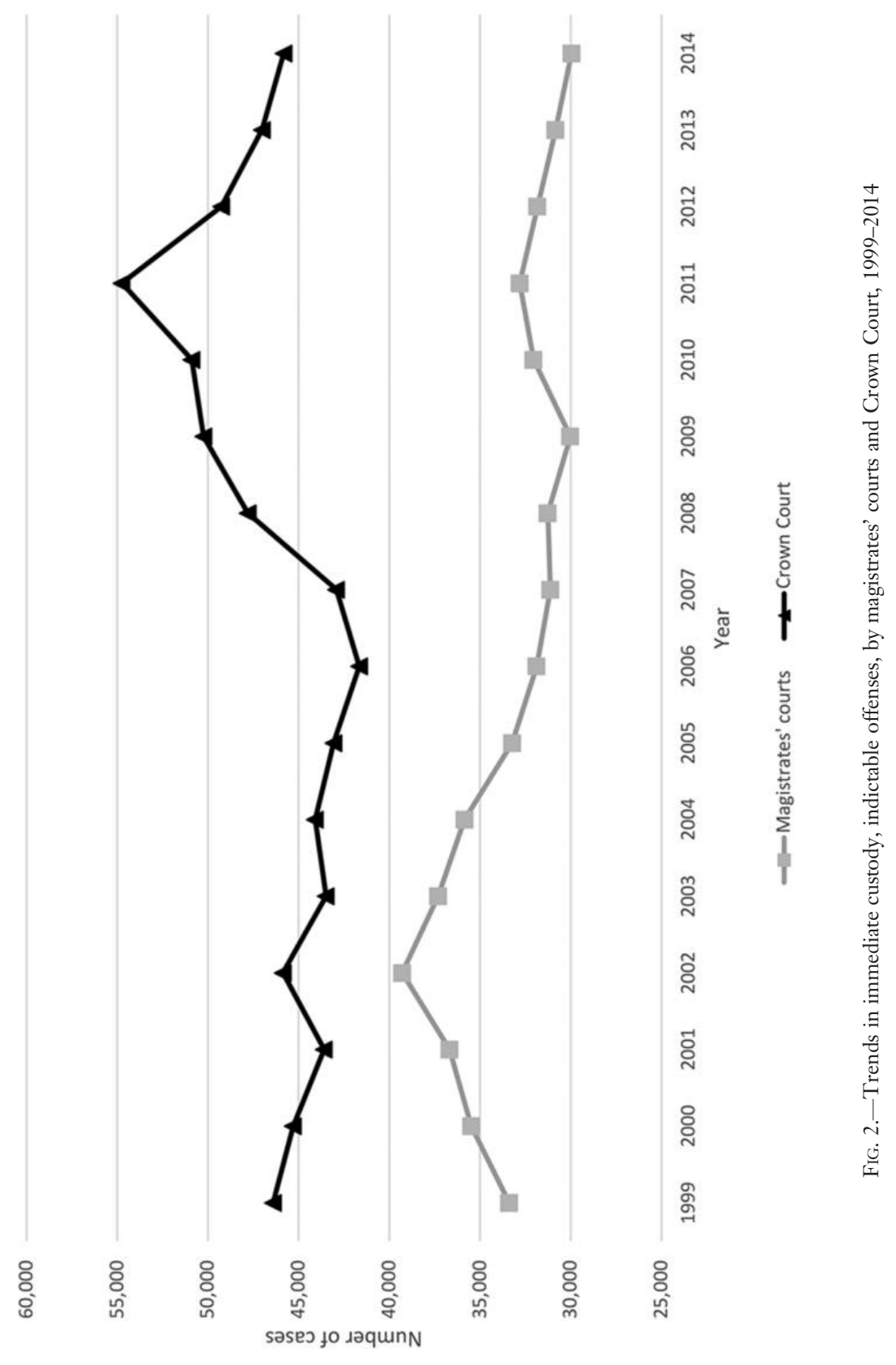




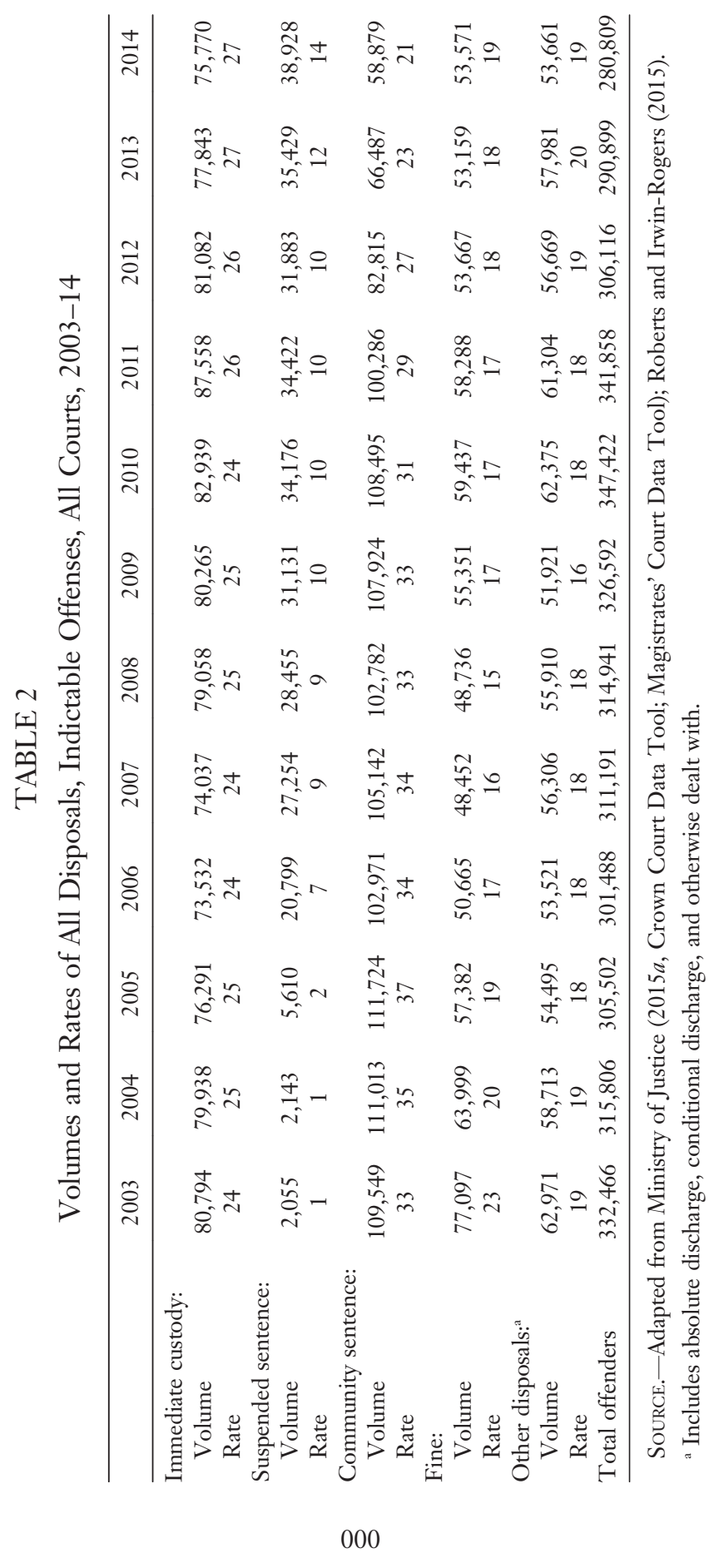

This content downloaded from 134.084.001.170 on June 25, 2016 03:24:58 AM

All use subject to University of Chicago Press Terms and Conditions (http://www.journals.uchicago.edu/t-and-c). 


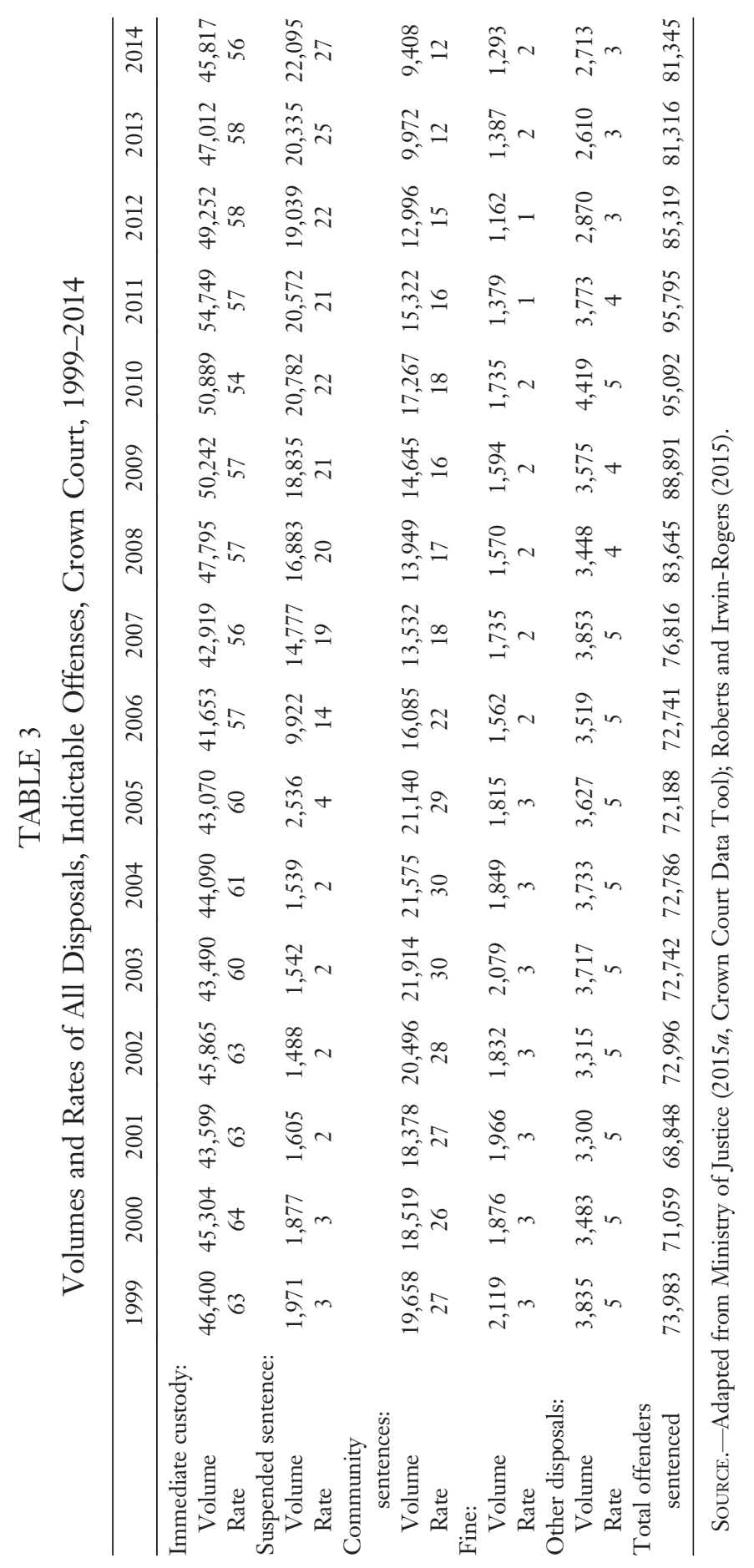

This content downloaded from 134.084.001.170 on June 25, 2016 03:24:58 AM

All use subject to University of Chicago Press Terms and Conditions (http://www.journals.uchicago.edu/t-and-c). 
with developments in other jurisdictions, most notably the Australian state of Victoria, where the suspended sentence has been abolished (Freiberg and Moore 2009).

In terms of numbers of cases, 2,055 offenders convicted in 2003 of an indictable offense received a suspended sentence; by 2014 this figure had risen to almost 40,000 (table 2). In terms of all sentenced cases the number rose from 2,717 in 2003 to 52,979 in 2014 (table 1). ${ }^{16}$ Table 4 focuses on the Crown Court and demonstrates that the increased use of the SSO occurred for all categories of offending. ${ }^{17}$

In other jurisdictions, the creation (or expansion) of sentences comparable to the suspended sentence has usually reduced the use of immediate sentences of imprisonment. ${ }^{18}$ This goal has not been achieved in England. Table 3 confirms this. As noted, the percentage of indictable cases in the Crown Court receiving an SSO rose from 4 percent in 2005 to 27 percent in 2014 (table 3); yet the proportionate use of immediate custody was relatively unchanged, dropping slightly from 60 percent of cases in 2005 to 56 percent in 2014. The Crown Court has experienced a steady and significant decline in the number of community orders. As seen in table 3, this disposal accounted for 29 percent of all Crown Court indictable cases in 2005; by 2014 this had declined to 12 percent.

Table 5 highlights the shift from community sentences to the SSO for violent offenses in the Crown Court. As can be seen, the proportion of custodial sentences for this category of offending was stable over the decade. The volume of community sentences imposed for crimes of violence dropped significantly, from one-third of all disposals in 2003 to less than one-tenth in 2014, while suspended sentences rose from 3 percent to 31 percent over the same period. Table 6 presents the same data for the magistrates' courts. Once again we see a dramatic increase in the use of suspended sentences-increasing from less than 1 percent of cases in 2003 to 17 percent in 2014. This was accompanied by an equally dramatic

\footnotetext{
${ }^{16}$ Although the very significant increase in the volume of SSOs has attracted little scholarly commentary or research, it has not escaped the attention of the news media or critical advocacy groups ("Almost 12,000 offenders walked free from court with suspended sentences" [Cuthbertson 2014]). Critics of the expanded use of the SSO have failed to appreciate that most of these cases would formerly have attracted a community order.

${ }^{17}$ Category-specific data are not yet available for 2013.

${ }^{18}$ For example, Lappi-Seppälä (2001) for Finland, Cid (2005) for Spain, and Roberts (2004) for Canada.
} 


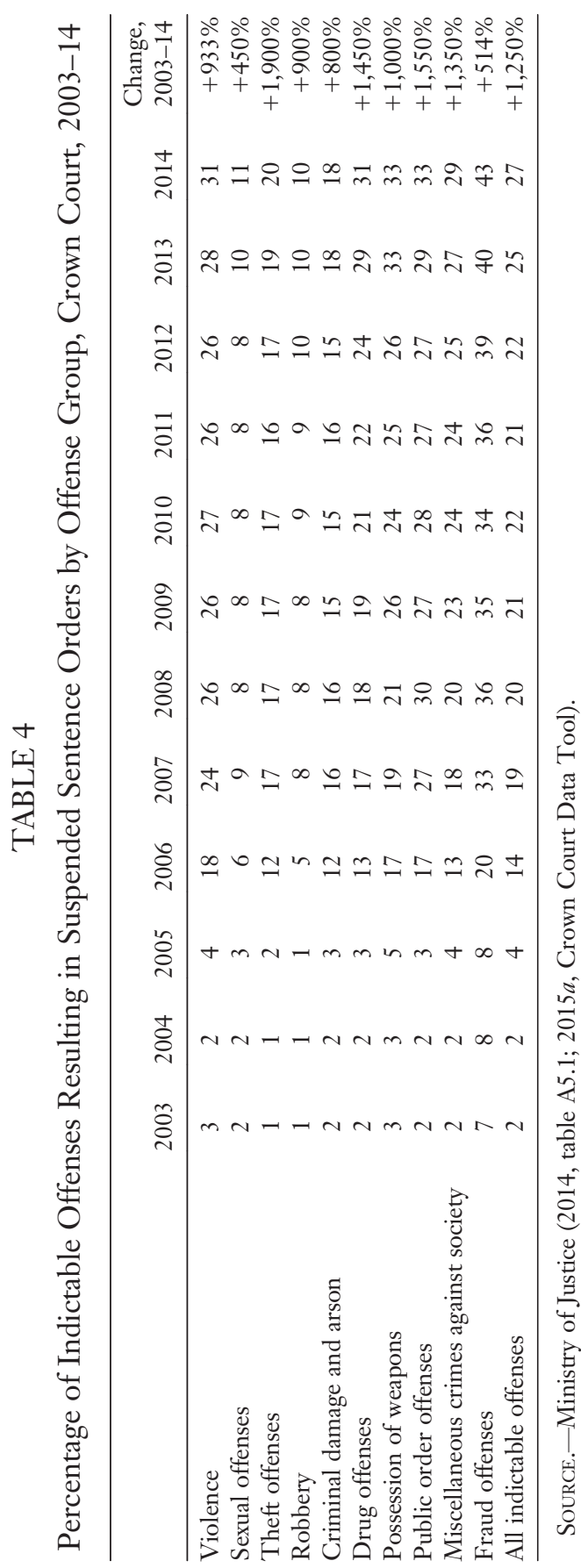

000 


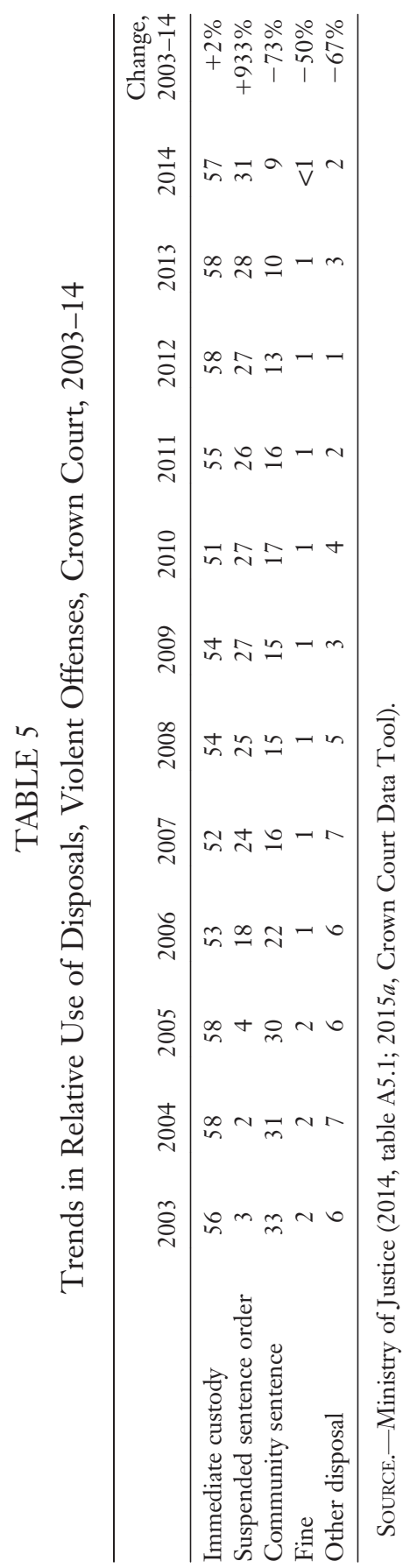

000 


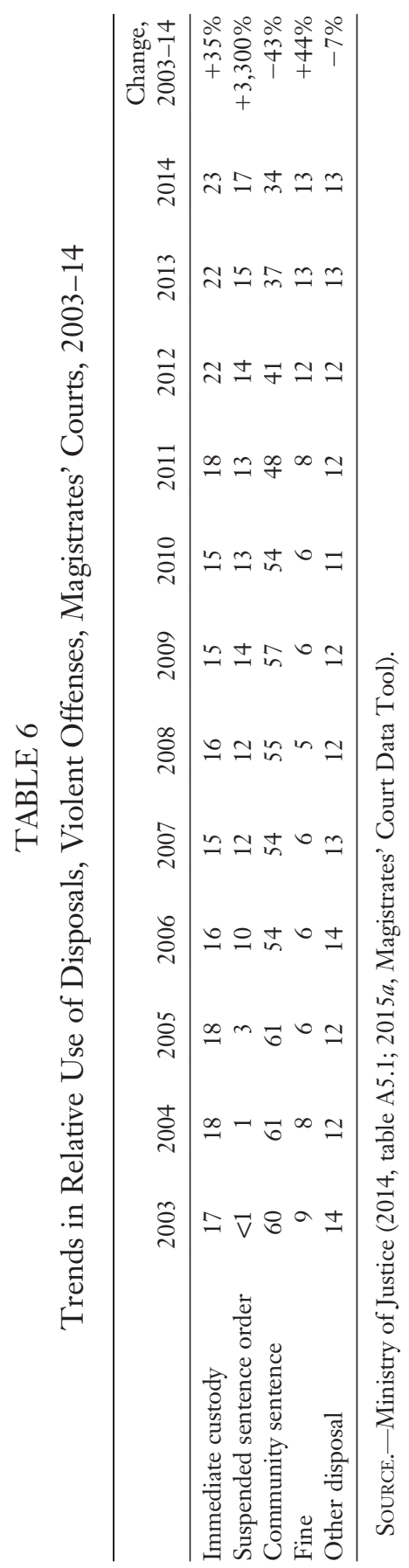

This content downloaded from 134.084.001.170 on June 25, 2016 03:24:58 AM 
fall in the use of community sentences, from 61 percent in 2003 to 34 percent in 2014, while the use of immediate custody increased (table 6).

\section{E. Evidence of "Net Widening"}

In light of the fact that an SSO has the legal status of a term of custody, it is surprising that the courts appear to be imposing it in cases that formerly attracted a community order. Numerous scholars (e.g., Ashworth and Player 2005; Wasik 2014; Ashworth 2015, pp. 318-22; Hedderman and Barnes 2015) have drawn attention to this example of "up-tariffing," which occurs when a sentence designed to replace immediate custody (because it is a form of custody) is ultimately applied to less serious cases (see Morris and Tonry 1990, pp. 156-57). Sparks (1971) and Bottoms (1981) found the same "malfunction" in the application of the suspended sentence to cases bound for a community sanction, following the introduction of the suspended sentence in the Criminal Justice Act 1967.

It is cause for concern that the SSO is being applied to cases that formerly would have attracted a noncustodial sentence. ${ }^{19}$ In other jurisdictions when a noninstitutional sentence of custody has been introduced that does not involve immediate imprisonment, the statutory framework requires courts to first impose a sentence of immediate imprisonment and only then to decide whether the sentence may be suspended. ${ }^{20}$ The guidance from the Sentencing Guidelines Council (2004) advocated this approach. The SGC specified a three-step methodology that courts should follow before imposing an SSO. First, a court has to find that the custodial threshold has been passed; second, it has to determine that custody is "unavoidable," and only then should it proceed to consider if the sentence may be suspended. Following this logic should ensure that all SSOs were cases for which immediate custody would otherwise have been imposed.

The statutory provision in England and Wales strongly suggests that suspending a sentence of imprisonment should take place only once a

\footnotetext{
${ }^{19}$ In one of the few empirical studies Mair, Cross, and Taylor (2008) report "persistent accounts of the misuse of the SSO on the part of magistrates" (p. 40).

${ }^{20}$ The suspended sentence in Spain carries this structure. The Canadian conditional sentence of imprisonment is in certain respects analogous to the SSO in that a term of institutional custody is imposed on the offender, who is then permitted to discharge the sentence in the community, usually at his residence. Failure to respect the conditions of the order normally results in a breach hearing and may ultimately lead to committal to custody (see Roberts 2004).
} 
court has established that the custodial threshold has been passed. The empirical trends noted here suggest that courts are imposing the SSO in a way that differs markedly from what was originally envisaged. They appear to be applying the suspended sentence to the more serious offenders within the community sentence caseload. Finally, the precise impact of the net widening on admissions to custody and the size of the prison population remains unquantified because data on the rate of breach and rate of admission to custody for breach are not currently published.

\section{F. Longer Sentences of Imprisonment}

A second important shift in sentencing practices relates to custodial sentence lengths. Table 7 summarizes the average custodial sentence length (ACSL) in months for both levels of court combined, 2003-14. As can be seen, across all offenses there has been an increase in ACSL from 12.6 months at the beginning of the decade to 15.6 in the most recent year (2014), an increase of approximately one-quarter. This reflects an increase in ACSL for indictable offenses from 15.7 to 18 months and, in particular, offenses involving violence and sexual offenses. Table 8 provides ACSL data for the two levels of court and demonstrates that the increase in ACSL arises from longer sentence lengths for indictable offenses in the Crown Court; sentence lengths declined somewhat for all cases sentenced in the magistrates' courts from 3.0 in 2003 to 2.4 months in 2014 (table 8). It is worth noting that the ACSL trends underestimate the true increase in time served in custody since they do not include the

\section{TABLE 7}

Average Custodial Sentence Length (in Months), All Courts, 2003-14

$\begin{array}{llllllllllll}2003 & 2004 & 2005 & 2006 & 2007 & 2008 & 2009 & 2010 & 2011 & 2012 & 2013 & 2014\end{array}$

\begin{tabular}{ccccccccccccc}
\hline $\begin{array}{c}\text { Indictable } \\
\text { offenses }\end{array}$ & 15.7 & 16.1 & 15.8 & 15.3 & 15.2 & 16.0 & 16.5 & 16.2 & 16.8 & 17.0 & 18.0 & 18.3 \\
$\begin{array}{c}\text { Summary } \\
\text { offenses }\end{array}$ & 3.2 & 3.2 & 3.1 & 3.0 & 3.0 & 2.8 & 2.8 & 2.7 & 2.6 & 2.7 & 2.7 & 2.6 \\
$\begin{array}{c}\text { All } \\
\text { offenses }\end{array}$ & 12.6 & 12.9 & 12.6 & 12.4 & 12.4 & 13.3 & 13.7 & 13.7 & 14.3 & 14.5 & 15.5 & 15.6 \\
\hline
\end{tabular}

SourCE.-Adapted from Ministry of Justice (2015a, table Q5.2); Roberts and IrwinRogers (2015). 


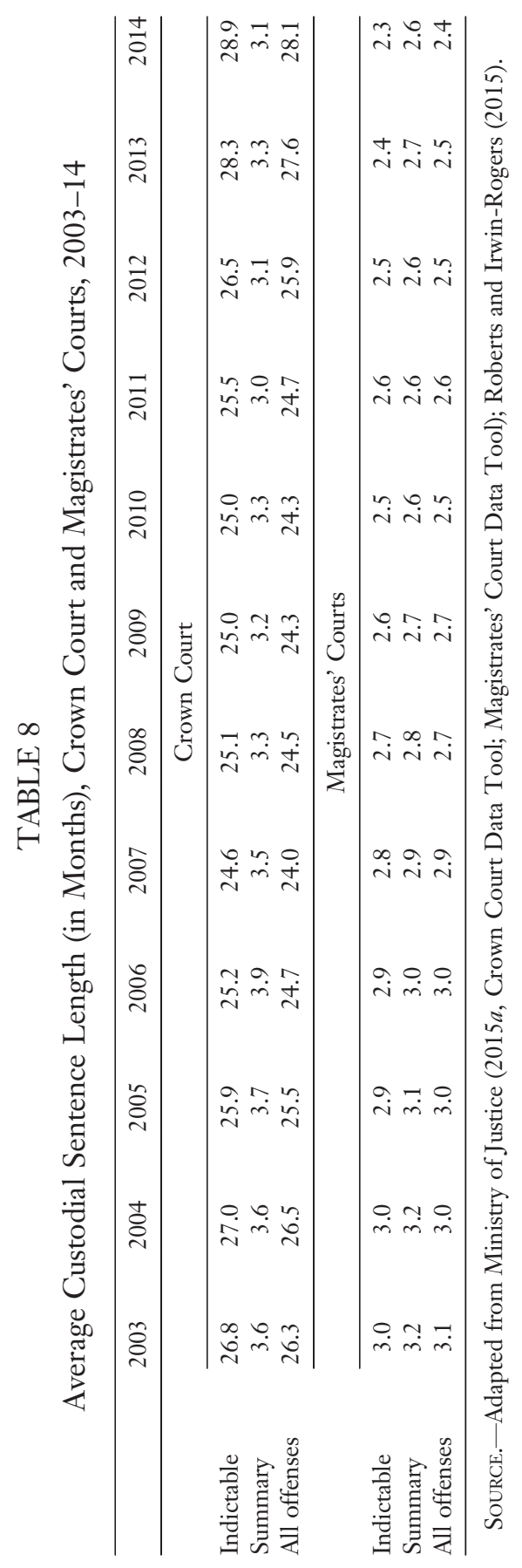

This content downloaded from 134.084.001.170 on June 25, 2016 03:24:58 AM 
significant number of indeterminate (i.e., Indeterminate Sentences for Public Protection, discussed below) cases.

Increases in sentence lengths were particularly striking for violent and sexual offenses. Table 9 reveals a 12 percent increase in ACSL for violent offenses and an even more striking 49 percent increase for sexual offenses over the period. Further research is needed to determine why these offense categories have attracted greater than average increases. It seems, however, that courts have focused the increased punitiveness on the more serious crimes of violence. Other serious violent crimes have seen similar increases. For example, the ACSL for manslaughter rose from 64 months in 2009 to 94.4 in 2014, an increase of 45 percent, and the average minimum term imposed on offenders convicted of murder rose from 14.5 years in 2004 to 21.2 years in 2014.

These latter changes may have been triggered by the introduction of Schedule 21 of the Criminal Justice Act 2003. This schedule introduced higher starting points for minimum terms for murder and has been criticized by scholars and the judiciary alike (e.g., Jeremy 2010; Wasik 2014). However, both the Sentencing Council and the Court of Appeal have taken the view that Parliament's approach to the minimum sentences for murder indicates that "crimes which result in death should be treated more seriously and dealt with more severely than before."21 Thus sentence levels for manslaughter, and also for attempted murder and causing grievous bodily harm with intent, have been raised to reflect this (Lord Phillips 2007).

\section{Sentencing Policy Developments, 2003-15}

The Criminal Justice Act 2003 reaffirmed a number of existing sentencing provisions and introduced a raft of changes. The objectives of sentencing were placed on a statutory footing for the first time, and guidance was provided regarding the use of prior convictions (see von Hirsch and Roberts 2004; Ashworth and Player 2005; Ashworth 2015). The 2003 act also established seriousness thresholds for the use of custodial sentences. Specifically, a sentencing court should impose custody only when no other sanction adequately reflects the seriousness of the crime (sec. 152 [2]). In addition, when imposing a term of custody, the court should employ the shortest period that is commensurate with

${ }^{21}$ The words of Lord Judge C. J. in $\operatorname{Wood}$ ([2010] 1 Cr App R (s) 6, at [23]). 


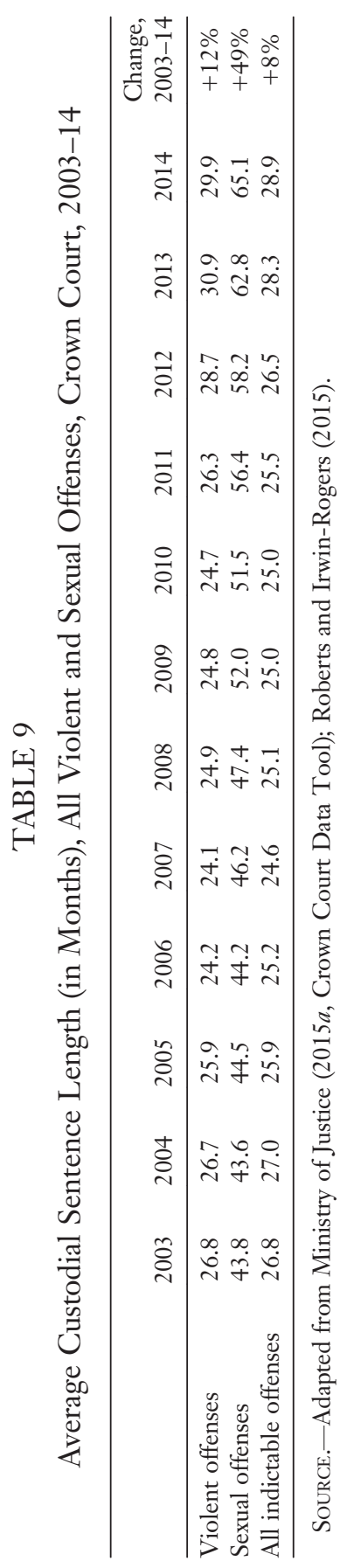

This content downloaded from 134.084.001.170 on June 25, 2016 03:24:58 AM 
the gravity of the offense (sec. 153 [2]). The extent to which these various statutory provisions are applied in practice remains an open question. Since 2003, a number of academics have argued that the custodial threshold is too easily crossed, too subjective, and in need of tightening (e.g., Padfield 2011).

The pace of change in sentencing legislation in England and Wales has been relentless over the last 12 years, as in the previous decade. Many of the changes have been designed to "toughen up" sentencing, and largely for political reasons, but that is by no means the whole story. Brief mention can be made here of four major policy developments or themes:

- the introduction of a new form of indeterminate sentence ("imprisonment for public protection,” or IPP) that was applied overextensively and swelled the prison population unexpectedly between 2005 and 2008, before a legislative retreat in 2008 and, ultimately, the abolition of IPP in 2012;

- the reshaping of community sentences and changing attitudes to breach of those sentences;

- the reform of the legal structure for the sentencing of youths in 2008, leading to a substantial reduction in the use of formal interventions and of custody for young offenders;

- a continuing refusal of governments to engage with — or even acknowledge - the recommendations made by independent inquiries into criminal justice, particularly in relation to the use of imprisonment.

\section{A. New Indeterminate Sentence: The IPP}

In 2002 the government set out to ensure "that the public are adequately protected from those offenders whose offense do not currently attract a maximum penalty of life imprisonment but who are nevertheless assessed as dangerous" (Home Office Sentencing Review 2001, para. 5.41). The 2003 act introduced the IPP, mandatory for offenders convicted of one of 153 offenses (some with maximum sentences as low as 5 or 3 years) who were presumed dangerous if they had a previous conviction for another such offense. Several thousand offenders were placed on IPP sentences, even in cases in which the minimum term (commensurate with the seriousness of their offense) was as low as 2 years or even 1 year. 
By 2008 the government recognized that indeterminate sentences were being significantly overused-creating injustice to offenders and unexpected strain on the prisons - and IPP was amended so as to make it discretionary rather than mandatory (see Jacobson and Hough 2010). The coalition government accepted that IPP was a mistaken policy, and it was abolished in 2012 and replaced by a much narrower provision. ${ }^{22}$ However, some 4,600 offenders remain in prison on indeterminate sentences, unable to persuade the Parole Board that they are suitable for release, ${ }^{23}$ and the European Court of Human Rights has held that their continued detention is not lawful. ${ }^{24}$

\section{B. Reshaping Community Sentences}

The government stated in 2002 that it wished to promote the wider use of community sentences while also making them tougher so as to increase the confidence of courts and the public. The Criminal Justice Act 2003 abolished distinct orders such as the probation order and the community service order in favor of a generic community sentence, with a range of 12 possible requirements (now increased to 15; Ashworth 2015 , pp. 359-70) including unpaid work, curfew, drug treatment, and so on. Courts were empowered to impose the requirements appropriate in each case. The 2003 act also toughened the provisions regulating judicial response to breach of a community order, with courts required to impose imprisonment if the breach is "willful and persistent."

Whether these changes would have led to greater use of community sentences was never tested as such, because, as explained in Section I, the 2003 act also reintroduced the suspended sentence and courts have preferred to make extensive use of it. In 2012, it was accepted that courts need greater flexibility when dealing with breach of a community sentence, and courts now have a wider range of options in response to breach. While there are good local initiatives in community sentences, courts seem to prefer the "bite" of a suspended sentence combined with one or more requirements, and it remains difficult to persuade courts to

\footnotetext{
${ }^{22}$ Under the Legal Aid, Sentencing and Punishment of Offenders Act 2012, a life sentence is "automatic" for offenders convicted of a second violent or sexual offense for which the (minimum) sentence for both offenses was 10 years or more.

${ }^{23}$ See www.parliament.uk/briefing-papers/Sn06086.pdf, p. 7.

${ }^{24}$ The British government has still not met the terms of the court's critical judgment in fames, Wells and Lee v. United Kingdom ([2013]) 56 E.H.R.R. 399).
} 
make significantly greater use of community sentences - as can be seen from the sentencing statistics summarized earlier.

\section{Reform of Youth Sentencing}

Youth court sentencing may be seen as one of the success stories of English sentencing and carries lessons for sentencing at the adult level. Largely owing to the work of the Youth Justice Board and its local agencies, the youth justice system in England and Wales has been substantially reoriented in the last decade. The principal legislative changes were made by the Criminal Justice and Immigration Act 2008: the referral order (referring the offender to a community-based Youth Offender Panel to consider the young offender's needs and how best to respond to them) was reinforced; for more serious offenders a youth rehabilitation order was introduced, with the requirements dependent on risks and needs, and for the most serious offenders, a youth rehabilitation order with intensive supervision and surveillance was introduced. Custodial sentences of detention and training remain for very serious offenders, but the court may not impose custody unless it is satisfied that the offender cannot properly be dealt with by a youth rehabilitation order. These legislative changes, reinforced by sentencing guidelines (Sentencing Guidelines Council 2009), succeeded in enhancing trends that had started a few years earlier. Thus the number of youths receiving their first caution or conviction exceeded 100,000 in the years 2005, 2006, and 2007 but had fallen spectacularly to 23,000 by 2013-14 (Youth Justice Board 2014). ${ }^{25}$ The number of youths in custody stood at 3,200 in 2002 but had declined to 1,056 by 2015 .

The Youth Justice Board had targeted localities with high custody rates and appears to have been successful in promoting alternative approaches (through restorative justice initiatives and new schemes for unpaid community work). The guidelines on the sentencing of youths (Sentencing Guidelines Council 2009) were used in training magistrates, and this may have assisted changes in practice. Although there remain concerns, such as the high reconviction rate of young offenders released from custody, this aspect of the English sentencing system has demonstrated that community sentences can be deployed successfully in place of many custodial sentences.

\footnotetext{
${ }^{25}$ In this context a "caution" (reprimand or warning) is an out-of-court response to an offense, which is administered by the police and recorded.
} 


\section{Independent Reports Critiquing the Use of Imprisonment}

We noted that the prison population in England and Wales doubled between 1993 and 2003. The resultant imprisonment rate is much higher than those in Germany, the Nordic countries, France, and Italy (see Sec. IV.B below). A review commissioned by the then government from Lord Carter (2007) recommended measures to reduce the use of custody (discussed below), but this part of his report was not adopted. The report of an independent inquiry into "English Prisons Today," sponsored by the Howard League, advocated greater "justice reinvestment" and more sparing use of custody (Howard League for Penal Reform 2010). A subsequent independent inquiry by the British Academy sets out a strong moral and political case against the current high use of imprisonment and argues for changes in the sentencing structure to reduce the reliance on prison sentences (British Academy 2014).

These well-reasoned reports, which rely considerably on comparisons with other European sentencing systems, have elicited no formal response from any government. Even where governments have taken notice of independent reports, such as Baroness Corston's (2007) report on women in the criminal justice system, progress has been desperately slow: the number of women in English prisons trebled between 1992 (1,500) and 2002 (4,500) before falling back only slightly to 4,200 in 2012 (on Scotland, see Angiolini [2012]). A review by the House of Commons Justice Committee (2013) found that most of the Corston recommendations had not been implemented.

One significant argument has been that penal policy should be removed from the political arena and placed in the hands of an independent body, following the transfer of major elements of British fiscal policy to an independent Monetary Policy Committee (Lacey 2008; British Academy 2014). No government has shown any enthusiasm for losing its power over sentencing policy, perhaps believing that greater penal severity is a vote-winning policy (cf. the surveys of public opinion by Hough and Roberts [2012] showing a more nuanced set of attitudes).

\section{Origin and Impact of the Sentencing Guidelines}

The most striking development in English sentencing since Ashworth (2001) was published is the inception and evolution of guidelines. The only guidelines at the time of the earlier review were voluntary guidelines published by the Magistrates' Association and occasional guideline 
judgments handed down by the Court of Appeal (Ashworth and Roberts $2013 a$, pp. 3-5). Since then, guidelines for most common offenses have been developed and now apply to both levels of court. In addition there is now a significant and growing body of empirical literature on the effects of the guidelines. For these reasons, the experience in this country carries important lessons for other countries contemplating introducing some form of guidelines.

Parliament created the Sentencing Advisory Panel in 1998, its principal role being to give advice to the Court of Appeal, having conducted a public and professional consultation on proposed guidelines. The Court of Appeal would then decide whether to adopt these guidelines in whole or in part and would incorporate them into a judgment of the court. Guideline judgments were issued for offenses such as burglary, handling stolen goods, and child pornography (Ashworth and Wasik 2010). However, following a major report on sentencing (Home Office for Penal Reform 2001), the Criminal Justice Act 2003 established the Sentencing Guidelines Council, with a judicial majority, to receive advice from the Sentencing Advisory Panel and to issue definitive guidelines. The SGC was itself required to consult the minister of justice and the relevant House of Commons committee on its draft proposals - a democratic input into the process, although the SGC retained power over the final contents of the guidelines.

A substantial number of definitive guidelines on topics such as sexual offenses, general principles, and youth sentencing were created during this period (see Ashworth 2006; Ashworth and Wasik 2010; Roberts 2012, 2015; Ashworth and Roberts 2013b; Wasik 2014).

In 2010, sentencing entered a new era. The Coroners and Justice Act 2009 had introduced important changes. These may be traced to two significant developments. The first was the review of the use of imprisonment in response to the high and rising prison population (Carter 2007). In 2007, Lord Carter recommended that the government "immediately implement a package of measures that could moderate the demand for custody" (p. 3). ${ }^{26}$ The second development was the creation

\footnotetext{
${ }^{26}$ Lord Carter set 2014 as the date by which the government should reduce the population by 4,500 places. So much for that deadline. The economic crisis that followed shortly after might have accelerated efforts to moderate the use of custody, although no such steps were undertaken. Prior to assuming power as the leading partner in the coalition government, the Conservative Party announced its opposition to a sentencing commission that was "simply a device to manage down the prison population" (p. 30).
} 
of the Sentencing Commission Working Group (SCWG). The SCWG reviewed sentencing guidelines in other jurisdictions and issued a public consultation document that attracted considerable response from the judiciary and other stakeholders (Jacobson, Roberts, and Hough 2008; Sentencing Commission Working Group 2008).

A consensus emerged from respondents that a grid-based guidelines system such as that found in several US jurisdictions was not appropriate for England and Wales. Instead of such a scheme, the SCWG recommended a revamp of the current arrangements. Both the Carter report and the report of the SCWG stressed the need for more accurate predictions of the prison population. Greater accuracy, it was argued, could be achieved if the government were better able to predict the use of sentences of imprisonment by the courts. This could be achieved by ensuring a tighter fit between the guidelines and judicial practice. These two reports spawned the Coroners and Justice Act 2009. This legislation introduced a number of changes to the sentencing guidelines.

\section{A. The Sentencing Council and Its Guidelines}

The act created a new statutory body - the Sentencing Council for England and Wales - to replace the previous two organizations. ${ }^{27}$ The new council retains a judicial majority among its 14 members. Before being replaced by the Sentencing Council in 2010, the Sentencing Guidelines Council had issued definitive guidelines for a range of offenses. These guidelines remain in force until such time as the Sentencing Council revises and reissues them - a task that will take several years to complete. In the meantime, the new council has issued a number of guidelines. The first such guideline relating to assault offenses was issued in March 2011. Since then the council has issued other offense-specific guidelinesfollowing a slightly different model — as well as "generic" guidelines relating to sentencing in multiple conviction cases and allocation decisions. ${ }^{28}$ In 2016, the council issued for consultation a guideline to replace the existing guideline relating to sentence reductions for a guilty plea.

\footnotetext{
${ }^{27}$ The Sentencing Advisory Panel (created in 1998) and the Sentencing Guidelines Council (in 2003).

${ }^{28}$ The guidelines pertain to burglary; environmental offenses; drug offenses; theft offenses; totality and offenses taken into consideration; sexual offenses; offenses involving dangerous dogs; fraud, bribery, and money laundering; health and safety offenses, corporate manslaughter, and food safety and hygiene offenses. All guidelines are available at http://sentencingcouncil.judiciary.gov.uk/.
} 
The English guidelines require a sentencing court to follow a clear methodology in determining sentence. For example, when sentencing an offender convicted of one of the assault offenses, a court should work through nine steps to arrive at a final sentence (Sentencing Council of England and Wales 2011). Thus, under the definitive guideline for causing grievous bodily harm, the first task (at step one) is to determine which of the three levels of seriousness is appropriate for the case appearing for sentence. The court must take into account an exhaustive list of the principal elements of the case appearing for sentencing - for example, the degree of premeditation and whether a vulnerable victim was deliberately targeted - to determine which of the three ranges is most appropriate. ${ }^{29}$ Thus the most serious cases that involve greater harm and higher culpability will fall into the category with the longest sentence length range (916 years). ${ }^{30}$

Once a court has determined the appropriate category range, it employs the starting point sentence within the range as a point of departure. For the most serious category, the starting point-from which a court will calculate a provisional sentence-is 12 years' custody. The second step involves adjusting the sentence within the chosen range by considering other factors deemed less important, such as previous convictions and personal mitigation. Having completed this step, the court then follows seven other steps to determine the final sentence. For example, step four requires a court to take into account whether and when the offender entered a guilty plea (Roberts and Rafferty 2011). ${ }^{31}$

\section{B. The Statutory Compliance Requirement}

Across many US guidelines, courts have to find "substantial and compelling" reasons to depart from the guidelines range. In England, the statutory compliance requirement is rather different and was amended as part of the most recent reforms. The Coroners and Justice Act 2009 amended the duty of a court to comply with the guidelines. Under the previous regime the statute stated that courts "must have regard" to

\footnotetext{
${ }^{29}$ These factors are all contained in an exhaustive list provided by the guideline.

${ }^{30}$ The ranges for the lesser categories are 5-9 years' custody for cases of intermediate seriousness and 3-5 years' custody for the least serious forms of causing grievous bodily harm with intent.

${ }^{31}$ The council has departed from this format for some of its more recent guidelines; see, e.g., the guideline for fraud, bribery, and money laundering offenses (Sentencing Council $2014 a)$.
} 
any relevant guidelines. Section 125 of the new act states that "(1) Every court: (a) must, in sentencing an offender, follow any sentencing guidelines which are relevant to the offender's case, and (b) must, in exercising any other function relating to the sentencing of offenders, follow any sentencing guidelines which are relevant to the exercise of that function, unless the court is satisfied that it would be contrary to the interests of justice to do so." This amended language thus tightened the compliance requirement on courts. However, in the process of legislative review, the requirement was softened by Parliament inserting clarification about the nature of a departure (Roberts 2011).

Courts may exercise their discretion in three important ways under the guidelines. First, although step one requires a court to identify an offense category and then apply that category's range, the guideline notes that courts may "move outside the category range" if they believe it is justified by the presence of a significant number of aggravating or mitigating factors. The guidelines proposed in New Zealand, in contrast, require the court that has chosen a range to remain within that range (Young and Browning 2008).

Second, having settled on a final sentence, a court is not bound to remain within the category range of the offense but only the much wider total guideline range. For example, consider the offense of assault occasioning actual bodily harm. If a court decides at step one that the case falls into the intermediate category of seriousness, it begins to work within a range running from a community order to 51 weeks' custody. However, for the purposes of complying with the statute, the court may impose any sentence within the total offense range that is much wider (from a fine to 3 years' imprisonment; see Ashworth 2010; Roberts 2012). Finally, a court may elect to depart from the guideline entirely if it decides that it would be contrary to the interests of justice to follow the guideline. The consequence is that courts have considerable discretion within the guideline ranges, as well as the ability to impose a sentence outside the range, if following the guideline would be contrary to the interests of justice.

The critical issue for present purposes is the relationship between the English guidelines and sentencing patterns, in particular the use of custody.

\section{Relationship between Use of Custody and Sentencing Guidelines}

Although the English council may be distinguished from its US counterparts on a number of dimensions, the principal distinguishing characteristic concerns its mandate. Many US states direct their sentenc- 
ing commissions to monitor sentencing practices and to adjust the guidelines in response to key changes, for example, in the size of the prison population. Frase (2005) observes that the Minnesota guidelines "were not expected simply to model and perpetuate past judicial decisions. ... The new guidelines were thus intended to be norm changing, not simply norm-reinforcing" (p. 146). Minnesota's was the first commission to take prison capacity and existing correctional resources into account when determining and revising guidelines (see Frase 2005). The Minnesota Commission was enabled to make policy decisions as well as to promote more consistent sentencing outcomes within the existing policy framework.

No such authority was conferred on the Sentencing Council of England and Wales. The SCWG created to explore the relationship between the guidelines and prison capacity ultimately rejected any link between the two. The SCWG concluded that "it is not practicable to impose a duty [on the Sentencing Guidelines] authority to . . . fit within current and reasonably foreseeable capacity" (2008, p. 28). This feature of the English guidelines has important consequences for the use of custody as a sanction. As seen in the empirical trends summarized in Section I, the guidelines have not constrained the use of custody as a sanction, nor has their onset been associated with any generalized escalation in severity. ${ }^{32}$ While sentence lengths have increased for indictable offenses in the Crown Court (particularly for violent and sexual offenses), this appears unrelated to the guidelines per se.

This outcome is unsurprising. In issuing guidance to courts, the Sentencing Council attempts to reproduce current judicial practice; the point of departure when devising or revising a guideline is existing practice as revealed by sentencing statistics, reported judgments, and transcript analyses. ${ }^{33}$ This point is confirmed by the council's resource impact assessments that are conducted prior to the development of each guideline. These assessments generally predict that the impact of the proposed guideline is neutral with respect to the number of prison places, exactly what one would expect if the guideline is based on existing prac-

\footnotetext{
${ }^{32}$ As noted later in the essay, the assault guideline appears to have triggered an escalation in severity for one offense.

${ }^{33}$ Current practice always has the point of departure for the development of guideline ranges. This is true of Minnesota in the late 1970s, Canada in the mid-1980s, and Uganda in 2013. Commissions differ in the degree to which their guidelines attempt to change existing sentencing patterns.
} 
tice (see, e.g., Sentencing Council 2014b). The guidelines are designed to have no impact on the prison population, and this is generally borne out in practice. The one exception to this is the assault guideline. A recent evaluation published by the Sentencing Council (2015b) revealed that for one assault offense (actual bodily harm) the introduction of the guideline had triggered a significant increase in sentence severity. ${ }^{34}$

The council has departed from established practice in only two examples, when current trends were regarded as being disproportionate. For example, in its drug offenses guideline the council recommends shorter sentence lengths for drug mules than would have been the case had it followed existing judicial practice. In general, however, the council's guidelines would appear to have been neutral with respect to the use of custody as a sanction, neither promoting nor discouraging courts from imposing custodial sentences.

Two explanations may be offered for the council's conservative policy regarding the use of custody. First, as a primarily judicial body, there is an understandable reluctance to engage with issues of sentencing policy; ${ }^{35}$ reducing the use of custody is seen by the judiciary as a matter left to the elected legislature to resolve. Indeed, other constituencies may also feel it is inappropriate for an unelected body to reduce (or inflate) custody rates or sentence lengths unless these changes are grounded in a principled or empirically derived justification. The English guidelines are designed to promote a "consistent approach to sentencing." Second, as noted, the mandate of the council contains no specific directive to consider the size of the prison estate when devising its guidelines nor to address racial or other disparities. Although we shall later note one statutory duty that could justify consideration of the cost-effectiveness of different disposals - with consequences for the size of the prison population - the council has developed its guidelines thus far without regard to the size of the prison population, although it has produced impact projections each time it has produced a guideline. ${ }^{36}$

\footnotetext{
${ }^{34}$ Presumably the council will address this inflationary effect when it revises the guideline and issues a revision for public consultation in 2016.

${ }^{35}$ Tonry (2004, p. 107) suggested that a primarily judicial majority is unwise because judges may constitute a force for conservatism.

${ }^{36}$ This exercise suggests that the council is not indifferent to the consequences of its guidelines on the size and costs of the prison estate.
} 
One response to the question "Why have the English guidelines not constrained the use of custody as a sanction, or promoted the use of alternatives to imprisonment?" might therefore be "Because the guidelines were not created with such objectives in mind." Yet there is a clear danger to the council's noninterventionist approach. By adopting judicial practice as the basis for its guidelines, the council not only fails to implement a more parsimonious approach to imprisonment; it also institutionalizes current judicial practice, for better or worse. ${ }^{37}$ If we assume, for the purposes of argument, that the recent increase in custody for sexual and violent offenses (e.g., table 7) was not caused by any changes in the seriousness of cases coming before the courts or prevented by the guidelines, then the shift will eventually be institutionalized by the council in its guidelines.

The statutory duties of the council do not preclude a more interventionist approach to sentencing practices, including shaping the use of custody as a sanction. For example, section 120 (11) of the Coroners and Justice Act 2009 directs that when exercising its functions relating to reviewing guidelines, the council "must have regard to" a series of considerations, one of which $(e)$ is "the cost of different sentences and their relative effectiveness in preventing reoffending." The council might draw on this statutory duty to justify promoting the use of alternative sanctions, particularly as a substitute for short prison sentences.

For example, the council could replace short prison sentences with community orders in some of its offense-specific guidelines. ${ }^{38}$ If the council were to accept that community orders represent a clearly more cost-effective punishment than, say, a 2-month prison term, it might adjust its guidelines accordingly. Substituting the community penalty for prison would be undertaken not in pursuit of a policy goal to reduce the size of the prison population but in recognition that short prison terms represent a more expensive way of achieving the statutory objectives of sentencing. To date, the council has declined to pursue such a policy change. Another approach would involve reacting to any upward

\footnotetext{
${ }^{37}$ It is significant that the guidelines do not include the statutory thresholds for different sanctions. It is assumed that the court will consider the thresholds, but highlighting them in the guideline would surely be a prudent step.

${ }^{38}$ Reducing the number of short prison terms would have only a modest impact on the prison population. Since these offenders serve such short prison terms, they represent less than 10 percent of the total population (see Mills 2011).
} 
or downward drift in sentencing practices. If a change was detected-for example, the striking increase in sentence length for sexual offenses-the council might determine if the shift was attributable to case characteristics or some legislative intervention such as a change in the maximum penalty. In the absence of a legitimate cause such as these, the council could issue guidance for the offenses affected by the change. Without such monitoring, the overall proportionality of the sentencing process may be undermined.

In the event, the council has declined to adopt these strategies, although academic commentators and a recent report funded by the British Academy have urged the council to "take a fresh look at its statutory duties and powers in relation to the costs and effectiveness of different forms of sentence" (British Academy 2014, p. 106). Without a more directive statute - one responsive to the size of the prison population or to the relative costs of imprisonment - the council is unlikely to change course.

Barely a year after the creation of the council in 2010, England experienced a rare but not unprecedented wave of social disorder. Riots erupted in a number of cities over the course of three nights in August 2011. In addition to a small number of extremely serious crimes, each affected city witnessed large numbers of offenders, primarily young adults, taking advantage of the disorder (Lewis 2011). The consequence was a sudden wave of expeditious prosecutions, most of which were for minor commercial burglary, as the offenders had stolen from looted or abandoned shops. The resulting sentencing was exemplary in severity; in some court locations the custody rate for commercial burglary doubled, and sentence lengths were significantly longer than those imposed prior to the riots. ${ }^{39}$

The sudden wave of prosecutions caused a short-term spike in the prison population. The riot prosecutions demonstrated both the limitations on the ability of the council to react expeditiously to a sentencing problem and the need for comprehensive guidelines. Since the council is required to conduct a protracted consultation on any proposed guideline, issuing timely guidance for courts on the question of how to sen-

\footnotetext{
${ }^{39}$ Ministry of Justice statistics reveal that the immediate custody rate in the Crown Court for offenses related to the public disorder was 81 percent compared to 33 percent for similar offenses committed a year earlier (Ministry of Justice 2012; for commentary, see Lightowlers and Quirk [2015]).
} 
tence offenses committed during such a period was impossible. Instead the Court of Appeal issued judgments that upheld strikingly harsher sentences in order to deter future cases. ${ }^{40}$ These judgments meant that offenders sentenced for riot-related offenses paid a much higher and quite unexpected premium for their offending. The council subsequently added the factor "offense committed during a period of social disorder" to all its subsequent guidelines, beginning with the burglary offenses guideline issued in 2012. The English riots illustrate the need for a sentencing guidelines authority to be able to respond immediately to such events, in order to preserve the principles that undermine sentencing and the sentencing guidelines.

\section{Effects of Guidelines on Consistency of Outcome and Application}

It is too soon to draw definitive conclusions about the effects of the guidelines on consistency and proportionality because the guidelines have been in place for a relatively short period and the evaluation research is limited. It takes a considerable amount of time to develop a guideline, issue it for public and professional consultation, and then revise it in response to feedback. The whole process takes approximately a year before a definitive guideline is issued. Nevertheless, some conclusions about the effects of the guidelines may be drawn. First, however, it is worth noting an important addition to the knowledge base of sentencing in this jurisdiction.

Between 2010 and 2015, sentencers in the Crown Court were required to complete a data form for every sentenced case. The council initiated this database to fulfill its statutory duty to monitor compliance with the guidelines. The survey was designed to produce a census rather than a sample of sentencing decisions in the Crown Court. The Crown Court Sentencing Survey (CCSS) form contained important elements of the offense and required the sentencer to indicate which guidelines factors were taken into account at sentencing. The data have been used by the Sentencing Council to develop and revise its guidelines and also to discharge its various statutory duties (Sentencing Council 2015b). Since the release of data to the public domain, the survey has been exploited by academic researchers (e.g., Raine and Dunstan 2009; Pina-

\footnotetext{
${ }^{40}$ The leading decision, handed down from the Court of Appeal by Lord Judge C. J., was Blackshaw ([2011] EWCA Crim 2312); for commentary, see Ashworth (2012) and Roberts (2012).
} 
Sanchez and Linacre 2013; Roberts 2013; Roberts and Pina-Sanchez 2014; Irwin-Rogers and Perry 2015; Maslen 2015). ${ }^{41}$

The Sentencing Council's survey provided unique insight into sentencing practices and goes far beyond merely documenting the extent to which courts comply with the council's guidelines. ${ }^{42}$ Information derived directly from the sentencer permits a much more accurate calibration of the influence of various factors on sentence outcomes. ${ }^{43}$ Unfortunately for researchers, in 2015 the council made the decision to terminate the Crown Court survey. The council took the view that the guidelines monitoring (which is a statutory requirement of the Coroners and Justice Act 2009) could be more efficiently achieved by time-limited and offense-specific data collection. This may be so, but the consequence is that the fine-grained, annual data that provided a unique insight into sentencing in the Crown Court will now be lost.

Although the council has a statutory duty to "monitor the operation and effect of its sentencing guidelines" and to "consider what conclusions can be drawn" from this monitoring (sec. 128 [1][a], [b]), this statutory obligation has been rather narrowly interpreted. The council publishes annual "departure" rates for offenses covered by its guidelines (e.g., Sentencing Council 2015b), but this report simply notes the percentage of cases falling outside the total offense ranges. Moreover, since the statutory definition of a departure sentence rests on the total offense range - rather than on the more limited guideline category range - for this reason alone, the departure rates are very low. For example, data from 2014 show that fully 97 percent of assault and burglary offenses fell within the overall guidelines range (Sentencing Council 2015a, tables $6.1,6.3)$.

${ }^{41}$ In 2013, the council made the first full year of data available to external researchers through its website.

${ }^{42}$ As far as we are aware, no other jurisdiction derives data directly from the sentencing authority, although some US guidelines require courts to complete a form in the event that a "departure" sentence is imposed (see Minnesota Sentencing Guidelines Commission 2015). As with all surveys, the CCSS had limitations, one of which is its coverage. In 2014, the response rate was approximately 65 percent (see Roberts and Hough [2015] and Sentencing Council [2015a] for further information and discussion).

${ }^{43}$ For example, research drawing on the CCSS has shown that sentence reductions for a guilty plea and sentence enhancements for previous convictions are both much more modest than would be thought from examination of the aggregate sentencing statistics. In the latter example, the ministry statistics include all relevant prior convictions, whereas the CCSS records only those that were considered relevant by the court at the time of sentencing (see Roberts and Pina-Sanchez 2014). This issue is discussed later in the essay. 
The creation of the Sentencing Council and the introduction of the guidelines have stimulated more academic scholarship and commentary. Padfield (2013) describes the increased debate on sentencing in the academic literature as "one of the greatest successes of the introduction of guidelines" (p. 50). Academic analyses to date suggest a positive impact on consistency across courts and also the application of the offensespecific guidelines. Pina-Sanchez and Linacre (2013) drew on the CCSS to explore the degree of variability in sentencing assault, robbery, and burglary. They demonstrated that for these offenses, the guideline factors were being applied in a consistent way across courts. Using a more sophisticated multivariate methodology than previous researchers, Pina-Sanchez (2015) explored the impact of the new assault guideline on variability in sentencing outcomes across courts. ${ }^{44} \mathrm{He}$ conducted a prepost analysis using the council's data set and reports that "consistency improved in all the offenses studied after the new guideline came into force" (p. 87). Irwin-Rogers and Perry (2015) drew on the same data set to explore the impact of sentencing factors in cases of domestic burglary. Their multivariate analyses "provided a strong indication that the courts were sentencing in a manner that was consistent with the domestic burglary guideline and in particular the principle that the factors in step one of the guideline should have more of an influence on sentence severity than the factors in step two" (p. 210). Finally, we noted earlier that the council's drug offenses guideline had attempted to change sentencing practices for so-called drug mules. Subsequent evaluation research by Fleetwood, Radcliffe, and Stevens (2015), again drawing on the CCSS, detected a significant downward shift in sentences imposed on these offenders to reflect their lower level of culpability. These researchers concluded that "the sentencing guideline appears to have achieved greater proportionality" (p. 435).

These findings with respect to sentencing trends, while restricted in time and scale, are encouraging. Additional research into public views of sentencing has suggested another benefit of the guidelines. One of the statutory duties of the Sentencing Council is to "have regard to . . . the need to promote public confidence in the criminal justice system" (Coroners and Justice Act 2009, art. 120[11][d]). One empirical explora-

\footnotetext{
${ }^{44}$ For example, Mason et al. (2007) were unable to control for a range of contaminating variables in their survey of sentencing variation across different court areas.
} 
tion of public opinion suggested that greater public awareness of the guideline may promote public confidence in sentencing and possibly mitigate criticism of sentencers. Members of the UK public were strongly supportive of the concept of guidelines. ${ }^{45}$ In addition, respondents who had been informed of the guidelines were less likely to rate specific sentences as being too lenient than people who reacted to the same cases without having been made aware of the guidelines (Roberts et al. 2012).

\section{E. "Glasnost" in English Sentencing}

Beyond more consistent and principled sentencing, guidelines confer benefits in ways that are not easily measured. A systematic and publicfacing set of guidelines also promotes greater understanding of sentencing and enhances the predictability of the sentencing process. The guideline regulating sentence reductions for a guilty plea is a good illustration of the greater transparency and predictability of sentencing practices since the onset of the guidelines. In almost all other common law jurisdictions, although the practice of awarding plea-based discounts is universal, the magnitude of these discounts remains hard to predict.

Canada is a good example of this lack of clarity. There is no guideline regulating sentence reductions and no appellate guidance regarding the appropriate levels of reductions (Renaud 2004, chap. 4). Moreover, since Statistics Canada does not record plea as a factor in its annual Adult Criminal Court Survey (personal communication, Canadian Centre for Justice Statistics, April 2013), researchers are unable to determine with any precision the magnitude of sentence reductions awarded by the courts. Accused persons contemplating entering a plea and who consult their legal advisors are unlikely to receive anything other than imprecise predictions regarding the benefit if they plead guilty. This undermines the purpose of sentence discounts, yet this constitutes the norm around much of the common law world. Litigants, advocates, and researchers - indeed, all interested parties - are better placed in England and Wales. ${ }^{46}$

\footnotetext{
${ }^{45}$ Ninety-three percent of respondents endorsed the view that guidelines were definitely or probably a good idea.

${ }^{46}$ Even in neighboring Scotland there is little clarity with respect to the magnitude of discounts, a sliding scale on the English model being rejected in Murray ([2013] HCJAC 129). This lack of clarity is self-defeating. As Leverick notes, "If defendants cannot predict with confidence that a discount will be awarded or suspect that it will be minimal, they may elect to take their chances at trial" (2014, p. 343).
} 
Greater clarity exists in England and Wales as a result of three significant developments. First, as noted, the individual guidelines themselves provide a relatively clear indication of the sentence ranges that may be imposed for specific offenses. Second, a generic guideline applicable across all offenses identifies specific levels of reduction that should be awarded to reflect a guilty plea. Third, the CCSS makes it possible to determine the extent to which the guidelines are actually followed in practice. ${ }^{47}$

The greater transparency and predictability introduced by the guidelines can be illustrated by reference to the guideline for plea-based sentence reductions. According to the current guideline (see Sentencing Guidelines Council 2007), if a guilty plea is entered at the earliest reasonable opportunity, the recommended reduction is one-third. ${ }^{48}$ The magnitude of the reduction should diminish the later the guilty plea is entered. For cases in which the plea was entered after the first reasonable opportunity but before the day of trial, the recommended reduction is one-quarter. Defendants who change their plea to guilty on the day the trial commences should receive a reduction of only 10 percent. The guideline thus creates a sliding scale of discounts depending on the timing of the plea, a pattern consistent with arrangements in other common law jurisdictions. ${ }^{49}$ Empirical research documents a relatively close fit between the guideline recommendations for guilty plea discounts and the reductions actually awarded in the Crown Court. Thus, while the guideline recommends a reduction of one-third for early plea cases, in 2012, four-fifths of offenders pleading at this stage of the process re-

\footnotetext{
${ }^{47}$ Although US commissions routinely monitor compliance with their guidelines, this has not been the case in England and Wales, until the creation of the Sentencing Council and the CCSS. The previous statutory body-the Sentencing Guidelines Council-did not have the resources to monitor judicial compliance with its guidelines.

${ }^{48}$ This guideline was issued by a former statutory body responsible for issuing guidelines and remains in effect until the current council issues a revised guideline. The council has a statutory duty to prepare a guilty plea reduction guideline (Coroners and Justice Act 2009, sec. 120[3][a]), and a draft for consultation was issued in 2016.

${ }^{49}$ Courts retain some discretion in determining the level of reduction awarded. The statutory foundation for the practice makes it clear that timing of the plea is not the only determinant of the reduction accorded. Section 144 (1) of the Criminal Justice Act 2003 notes two elements, and not simply the timing: "In determining what sentence to pass on an offender who has pleaded guilty to an offence in proceedings before that or another court, a court must take into account: (a) the stage in the proceedings for the offence at which the offender indicated his intention to plead guilty, and (b) the circumstances in which this indication was given" (emphasis added).
} 
ceived exactly this level of reduction. The remaining cases can be explained by the presence of factors other than the timing of the plea that also affect the magnitude of the reduction (see Roberts 2013). ${ }^{50}$

One of the four key objectives of sentencing reform identified by the SCWG in 2008 was to achieve "transparency," which it defined as the "ability of Parliament, the public, and sentencers to have an understanding, through the existence of clear and comprehensive sentencing guidelines ... of how offenders may expect to be sentenced, together with an understanding of the aggravating and mitigating factors that may be taken into account" $(2008$, p. 8$) .{ }^{51}$ If the guidelines have failed to achieve some other important goals, they have at least made significant progress toward this objective.

\section{Conclusions}

This essay has discussed the major changes taking place in sentencing in England and Wales between 2003 and 2015. Much more could have been said about the sentencing policies pursued by the Court of Appeal (on which see Ashworth [2015], especially chap. 9), which continue to have a significant effect despite the proliferation of sentencing guidelines. There has also been an expansion in the use of civil preventive orders, imposed by civil or criminal courts so as to prohibit certain forms of conduct, with a maximum sentence of 5 years' imprisonment for breach of the order (Ramsay 2013; Ashworth and Zedner 2014, chap. 4), and an increase in the use of out-of-court punishments (Padfield, Morgan, and Maguire 2012). Without elaborating on these and other tendencies, however, we conclude here by identifying three major themes in recent English policy:

- the continued attraction of penal populism to policy makers, despite empirical findings showing that members of the public are accepting of alternatives to custody, particularly when the alternatives carry cost savings;

\footnotetext{
${ }^{50}$ The correspondence between empirical reductions and guideline recommendations becomes weaker for the late plea cases simply because a number of other factors come into play (see Roberts and Bradford 2015, table 2).

${ }_{51}$ The other three objectives were predictability, consistency, and compatibility between the supply of and demand for correctional capacity (see pp. 8-9).
} 
- the relatively high use of imprisonment compared with countries such as Germany (and several other European countries) and, in particular, the high use of indeterminate sentences;

- the continued resistance of the British government to judgments of the European Court of Human Rights relating to imprisonment, manifested in a refusal to implement certain judgments.

\section{A. Penal Populism and Public Opinion}

Sentencing policy continues to be driven by political initiatives, despite evidence that a uniformly punitive approach to punishing offenders is inconsistent with community views. A number of empirical investigations in recent years have documented public tolerance of alternatives to custody. For example, Roberts and Hough (2011) document widespread public support for a range of mitigating factors at sentencing. Research has demonstrated that the public is sensitive to the issue of costeffectiveness, even if the political parties remain committed to custody whatever the cost. With respect to alternatives to custody, although the government may not see community sentences and custody as fungible, the public appears to think differently. In addition, there is acceptance of alternatives to custody for a range of offenses (Roberts and Hough 2011).

The most compelling example of political indifference regarding current levels of punishment comes from the period of austerity triggered by the worldwide recession of 2008. The UK government has implemented spending cuts throughout all public services, including criminal justice. Yet the cuts to the criminal justice system have deliberately avoided reducing the use of custody as a sanction. Instead, the government has targeted the legal aid budget and introduced a raft of reductions to policing and central departments such as the Ministry of Justice. This reluctance to promote alternatives is even more surprising in light of the ministry's own research having demonstrated that short-term custody (less than 12 months in prison) was consistently associated with higher rates of proven reoffending than community orders and SSOs (Mews et al. 2015).

With respect to prisons, the current Conservative government has required institutions to reduce the average amount spent per prisoner. ${ }^{52}$

\footnotetext{
${ }^{52}$ In 2014, the coalition government detailed plans to cut the average annual cost of incarceration by $£ 2,200$ per inmate.
} 
This strategy is tantamount to attempting to reduce the costs of Accident and Emergency Departments by lowering the average costs, per patient treated, rather than restricting admissions to only those patients who cannot be treated elsewhere. The National Health Service has introduced a number of strategies to reduce the caseload of Accident and Emergency through creation of out-of-hours clinics and on-site general practitioner screening to determine whether a patient presenting at a hospital needs to be admitted or can be safely treated elsewhere. No analogous filtering strategy has been considered to reduce the caseload of the prison estate, which continues to silt up with the penal equivalent of "bed blockers," namely, individuals who could have been equally or more effectively punished in the community or who are serving longer terms than can reasonably be justified on the grounds of desert or dangerousness.

The attitude of successive governments, coupled with the restricted mandate and conservative approach of the Sentencing Council to modifying sentencing practices, leads us to conclude that the custody rate is unlikely to change in the near future. Indeed, according to the latest government estimates, the prison population is projected to increase still further, by 9 percent over the period 2016-20 (Ministry of Justice $2015 d$, p. 2). Aside from a few limited initiatives, the government appears to be content to let the use of custody remain at the current level and to focus on increasing the accuracy of prison projections. The eventual release of the IPP population will help constrain the numbers of prisoners, but the overall picture will likely remain unchanged.

\section{B. High Use of Imprisonment}

World prison statistics show that the imprisonment rate per 100,000 of population currently stands at around 148 for England and Wales, compared with 79 for Germany and around 70 for the Nordic countries, and 98 for France (Walmsley 2013). Can this relatively high rate be credited with the decline in recorded crimes in England and Wales? Has the high use of custody served to prevent crime? This seems highly unlikely, since the institution of punishment does not exist in a social vacuum, but rather in "broad socioeconomic, cultural, and political conditions" (Lacey 2008, p. 19). Thus the corporatist approach in Germany means that there is little political or legal discussion of sentencing reform, and moderate sentencing levels are sustained by institutional features such as the form of German legal education (inculcating certain 
values) and the selection of career judges from the top law school graduates (Hoernle 2013). While it is true that crime rates in England and Wales have declined as levels of imprisonment have increased, the causal inference has to be examined with care: in common with almost all other European countries, France and Germany, which have not had a significant increase in the use of imprisonment, have also experienced declines in their crime rates in recent years.

The high use of imprisonment in England and Wales (relative to many other EU member states) has occurred largely for other reasons, perhaps connected to the nature of the political system, perhaps reflecting changes in the labor market and other economic factors, perhaps as a consequence of changes in the welfare system (Lacey 2008; Wacquant 2009). Thus Lappi-Seppälä (2013) concludes from his European study that "overall victimization rates ... are unrelated to incarceration rates" (p. 312), although he also warns that the available data are more satisfactory for homicide than for many other types of crime. Our argument here is that serious questions should be asked about the justifications for the current level of imprisonment in England and Wales, relative to other western European countries, not least in respect of the length of English sentences and the extraordinary fact that 19 percent of prisoners are serving indeterminate sentences.

\section{Resistance to Fudgments of the European Court of Human Rights}

The British government is a signatory to the European Convention on Human Rights and has agreed to abide by the judgments of the European Court of Human Rights in Strasbourg. However, in recent years some of those judgments have met with resistance from the UK Supreme Court or from the British government. The first of four examples is the judgment in Stafford v. United Kingdom ([2002] 35 E.H.R.R. 1121), in which the Strasbourg Court held that the determination of release from a sentence of life imprisonment was a sentencing matter and that it should therefore be decided by an "impartial and independent tribunal" and not by a government minister. This judgment was accepted, but the system of sentencing for murder was hastily changed by Schedule 21 to the Criminal Justice Act 2003 - discussed at the end of Section I above - in which Parliament created significantly higher starting points for minimum terms for murder sentences.

The second example is Hirst v. United Kingdom ([2006] 42 E.H.R.R. 41), in which the Strasbourg Court held that the "general, automatic, 
and indiscriminate" ban on prisoners voting was a disproportionate restriction on an important human right. The British government disagrees with this judgment and has not implemented it, even though the judgment would not prevent a more nuanced ban on voting. A third case is fames, Wells and Lee v. United Kingdom (2013), already mentioned (see fn. 24), where the Court held that it is unlawful to detain prisoners sentenced to the indeterminate IPP sentence without providing courses that enable them to present a case for release from custody. Over 4,600 IPP prisoners remain in prison after the expiration of the minimum term of their sentences (see fn. 22).

Finally, the British government has signaled its intention not to comply with the judgment in Vinter v. United Kingdom ([2014] Crim.L.R. 81) on life imprisonment with a whole life order (the equivalent of life without parole in the United States). The Court's view is that human dignity requires that there must always be the possibility of review of the need for continuing detention. There is disagreement about whether English law provides for this, but the Strasbourg Court has now accepted that English law does ensure compliance because the minister for justice is bound to act compatibly with article $3 .{ }^{53}$ While there are other important judgments with which the United Kingdom has complied, the growing resistance to Strasbourg in matters surrounding imprisonment represents a major challenge to the European system for the protection of human rights.

\section{Coda}

Notwithstanding their limitations and critics, the guidelines remain the most positive story emerging from England and Wales. ${ }^{54}$ As noted, they have not constrained the use of custody, nor has the council elected to promote a more cost-effective approach to sentencing. However, the existence of guidelines containing sentence ranges means that a mecha-

\footnotetext{
${ }^{53}$ In Hutchinson v. United Kingdom, judgment of February 3, 2015; this case has now been referred to the Grand Chamber, which means that another judgment on this issue is imminent.

${ }^{54}$ As is the case in other jurisdictions, the guidelines have also attracted critics. One critique expressed by some scholars and practitioners is that the guidelines have diminished the role of personal mitigation at sentencing (e.g., Lovegrove 2010; Cooper 2013; cf. Roberts, Hough, and Ashworth 2011). Academics have also criticized the guidelines for providing insufficient guidance regarding the weighting that should be assigned different factors (Dhami 2013). Padfield (2013) has questioned whether the guidelines have successfully ensured fairer and more consistent outcomes, and a recurrent critique is that not-
} 
nism is in place that could comprehensively reduce the use of custody and in a principled fashion, if the political will were to emerge. In light of the government's austerity drive in almost all areas of public expenditure, it may well eventually seek to reduce the current use of imprisonment as a sanction, if only to ensure cost cutting across all sectors. Finally, the guidelines have increased transparency and predictability of sentencing to a greater level than most other common law jurisdictions. If not justifying celebration, this last development is at least cause for some satisfaction.

\section{REFERENCES}

Advisory Council on the Penal System. 1978. Sentences of Imprisonment: Report of the Advisory Council on the Penal System. London: HMSO.

Angiolini, Elish. 2012. Report of the Commission on Women Offenders. Scottish Executive, Edinburgh. http://www.gov.scot/resource/0039/00391828.pdf.

Ashworth, Andrew. 2001. "The Decline of English Sentencing." In Sentencing and Sanctions in Western Countries, edited by Michael Tonry and Richard S. Frase. New York: Oxford University Press.

_. 2006. "The Sentencing Guideline System in England and Wales." South African Fournal of Criminal fustice 19:1-23.

- 2010. "Coroners and Justice Act 2009: Sentencing Guidelines and the Sentencing Council." Criminal Law Review (5):389-401.

. 2012. "Departures from the Sentencing Guidelines." Criminal Law Review (2):81-96.

. 2015. Sentencing and Criminal fustice. 6th ed. Cambridge: Cambridge University Press.

Ashworth, Andrew, and Elaine Player. 2005. "Criminal Justice Act 2003: The Sentencing Provisions." Modern Law Review 68(5):822-38.

Ashworth, Andrew, and Julian Roberts. 2013a. "The Origins and Evolution of Sentencing Guidelines in England and Wales." In Sentencing Guidelines: Exploring the English Model, edited by Andrew Ashworth and Julian Roberts. Oxford: Oxford University Press.

. 2013b. Sentencing Guidelines: Exploring the English Model. Oxford: Oxford University Press.

_. 2016. "Sentencing: Theory, Policy, and Practice." In Oxford Handbook of Criminology, 5th ed., edited by Shadd Maruna, Lesley McAra, and Alison Liebling. Oxford: Oxford University Press.

Ashworth, Andrew, and Martin Wasik. 2010. "Ten Years of the Sentencing Advisory Panel.” Annual report. http://www.sentencing.council.org.

withstanding the 2009 amendments to the compliance requirement, the guidelines still permit too much judicial discretion at sentencing (e.g., Ashworth 2010; Young and King 2013). 
Ashworth, Andrew, and Lucia Zedner. 2014. Preventive fustice. Oxford: Oxford University Press.

Bottoms, Anthony. 1981. "The Suspended Sentence in England, 1967-1978." British Fournal of Criminology 21:1-26.

British Academy. 2014. A Presumption against Imprisonment. London: British Academy.

Carter, Lord. 2007. Securing the Future: Proposals for the Efficient and Sustainable Use of Custody in England and Wales. London: Ministry of Justice.

Cid, Josép. 2005. "Suspended Sentences in Spain: Decarceration and Recidivism." Fournal of Community and Criminal fustice 52(2):169-79.

Cooper, John. 2013. "Nothing Personal." In Sentencing Guidelines: Exploring the English Model, edited by Andrew Ashworth and Julian Roberts. Oxford: Oxford University Press.

Corston, Baroness. 2007. Review of Women with Particular Vulnerabilities in the Criminal Fustice System. London: Home Office.

Cox, Edward. 1877. The Principles of Punishment, as Applied in the Administration of Criminal Law by Judges and Magistrates. London: Law Times Office.

Crackenthorpe, M. 1900. "Can Sentences Be Standardised?” Nineteenth Century (January):103-15.

Cross, Rupert. 1971. The English Sentencing System. London: Butterworths.

Cuthbertson, Peter. 2014. Suspended Sentences: The Case for Abolition. London: Centre for Crime Prevention. https://drive.google.com/file/d/0B25IaOtJK1 vwam5mREhqU3JQUVE/edit?pli $=1$.

Dhami, Mandeep. 2013. "A 'Decision Science' Perspective on the Old and New Sentencing Guidelines in England and Wales." In Sentencing Guidelines: Exploring the English Model, edited by Andrew Ashworth and Julian Roberts. Oxford: Oxford University Press.

Fleetwood, Jennifer, Polly Radcliffe, and Alex Stevens. 2015. "Shorter Sentences for Drug Mules: The Early Impact of the Sentencing Guidelines in England and Wales." Druos: Education, Prevention and Policy 22(5):428-36.

Frase, Richard S. 2005. "Sentencing Guidelines in Minnesota, 1978-2003." In Crime and 7ustice: A Review of Research, vol. 32, edited by Michael Tonry. Chicago: University of Chicago Press.

Freiberg, Arie, and Victoria Moore. 2009. "Disbelieving Suspense: Suspended Sentences of Imprisonment and Public Confidence in the Criminal Justice System." Australia and New Zealand 7ournal of Criminology 42(1):101-22.

Galton, Francis. 1895. "Terms of Imprisonment." Nature 52(1338):174-76.

Hedderman, Carol, and Rebecca Barnes. 2015. "Sentencing Women: An Analysis of Recent Trends." In Exploring Sentencing Practice in England and Wales, edited by Julian Roberts. London: Palgrave Macmillan.

Hoernle, Tatjana. 2013. "Moderate and Non-arbitrary Sentencing without Guidelines: The German Experience." Law and Contemporary Problems 76 (1):189-210.

Home Office Sentencing Review 2001. Making Punishments Work. London: Home Office.

Hough, Mike, Jessica Jacobson, and Andrew Millie. 2003. The Decision to Imprison: Sentencing and the Prison Population. London: Prison Reform Trust. 
Hough, Mike, and Julian Roberts. 2012. "Public Opinion, Crime, and Criminal Justice." In Oxford Handbook of Criminology, 5th ed., edited by Mike Maguire, Rod Morgan, and Robert Reiner. Oxford: Oxford University Press.

House of Commons Justice Committee. 2013. Women Offenders: After the Corston Report. HC 92. London: HMSO.

Howard League for Penal Reform. 2010. Do Better, Do Less: Report of the Commission on English Prisons Today. London: Howard League for Penal Reform.

Irwin-Rogers, Keir, and Thomas Perry. 2015. "Exploring the Impact of Sentencing Factors on Sentencing Domestic Burglary." In Exploring Sentencing Practice in England and Wales, edited by Julian Roberts. London: Palgrave Macmillan.

Jacobson, Jessica, and Mike Hough. 2010. Unjust Deserts: Imprisonment for Public Protection. London: Prison Reform Trust.

Jacobson, Jessica, Julian Roberts, and Mike Hough. 2008. "Towards More Consistent and Predictable Sentencing in England and Wales." In Tackling Prison Overcrowding: Build More Prisons? Sentence Fewer Offenders? edited by Mike Hough, Rob Allen, and Enver Solomon. Bristol: Policy Press.

Jeremy, David. 2010. "Sentencing Policy or Short-Term Expediency?" Criminal Law Review (8):593-607.

Kamuzze, Juliet. 2014. “An Insight into Uganda's New Sentencing Guidelines: A Replica of Individualization?" Federal Sentencing Reporter 27(1):47-55.

Lacey, Nicola. 2008. The Prisoners' Dilemma. Cambridge: Cambridge University Press.

Lappi-Seppälä, Tapio. 2001. "Sentencing and Punishment in Finland: The Decline of the Repressive Ideal." In Sentencing and Sanctions in Western Countries, edited by Michael Tonry and Richard S. Frase. New York: Oxford University Press.

2013. "Imprisonment and Penal Demands: Exploring the Dimensions and Drivers of Systemic and Attitudinal Punitivity." In European Handbook of Criminology, edited by Sophie Body-Gendrot, Mike Hough, Klara Kerezsi, Rene Levy, and Sonja Snacken. New York: Routledge.

Leverick, Fiona. 2014. "Sentence Discounting for Guilty Pleas: An Argument for Certainty over Discretion." Criminal Law Review (6):338-49.

Lewis, Paul. 2011. Reading the Riots: Investigating England's Summers of Disorder. London: London School of Economics. http://eprints.lse.ac.uk/46297/1.

Lightowlers, Carly, and Hannah Quirk. 2015. "The 2011 English 'Riots': Prosecutorial Zeal and Judicial Abandon.” British 7ournal of Criminology 55(1):6585 .

Lovegrove, Austin. 2010. "The Sentencing Council, the Public's Sense of Justice, and Personal Mitigation." Criminal Law Review (12):906-23.

Mair, George, Noel Cross, and Stuart Taylor. 2008. The Community Order and the Suspended Sentence Order: The Views and Attitudes of Sentencers. London: Centre for Crime and Justice Studies.

Maslen, Hannah. 2015. "Penitence and Persistence: How Should Sentencing Factors Interact?" In Exploring Sentencing Practice in England and Wales, edited by Julian Roberts. London: Palgrave Macmillan. 
Mason, Thomas, Nisha de Silva, Nalini Sharma, David Brown, and Gemma Harper. 2007. Local Variation in Sentencing in England and Wales. London: Ministry of Justice.

Mews, Aidan, Joseph Hillier, Michael McHugh, and Cris Coxon. 2015. The Impact of Short Custodial Sentences, Community Orders and Suspended Sentence Orders on Re-offending. London: Ministry of Justice.

Mills, Helen. 2011. "The 'Alternative to Custody' Myth." Criminal 7ustice Matters (March):34-36.

Ministry of Justice. 2012. Statistical Bulletin on the Public Disorder of 6th to 9th August 2011-September 2012 Update. London: Ministry of Justice.

. 2013. Story of the Prison Population: 1993-2012. London: Ministry of Justice. . 2014. Criminal Fustice Statistics Quarterly: December 2013. Sentencing Data Tool. https://www.gov.uk/government/statistics/criminal-justice-system -statistics-quarterly-december-2014.

- 2015a. Criminal Fustice System Statistics Quarterly December 2014. Sentencing Data Tool. https://www.gov.uk/government/statistics/criminal-justice -system-statistics-quarterly-december-2014.

- 2015b. Offender Management Statistics Quarterly: Prison Population: 30 September 2015. London: Ministry of Justice.

- 2015c. Prison Population Figures 2015: Population Bulletin: Weekly 27 November 2015. London: Ministry of Justice.

- 2015d. Prison Population Projections, 2015-2021: England and Wales. Statistical Bulletin. London: Ministry of Justice.

Minnesota Sentencing Guidelines Commission. 2015. Minnesota Sentencing Guidelines and Commentary. Minneapolis: MSGC.

Morris, Norval, and Michael Tonry. 1990. Between Prison and Probation. New York: Oxford University Press.

Padfield, Nicola. 2011. "Time to Bury the Custody Threshold?" Criminal Law Review (8):593-612.

_ 2013. "Exploring the Success of Sentencing Guidelines." In Sentencing Guidelines: Exploring the English Model, edited by Andrew Ashworth and Julian Roberts. Oxford: Oxford University Press.

Padfield, Nicola, Rod Morgan, and Mike Maguire. 2012. "Out of Court, Out of Sight? Criminal Sanctions and Non-judicial Decision Making." In Oxford Handbook of Criminology, 5th ed., edited by Mike Maguire, Rod Morgan, and Robert Reiner. Oxford: Oxford University Press.

Park, Hyungkwan. 2010. "The Basic Features of the First Korean Sentencing Guidelines." Federal Sentencing Reporter 22:262-71.

Phillips of Worth Matravers, Lord. 2007. "How Important Is Punishment?" Speech to the Howard League for Penal Reform, London, November 15.

Pina-Sanchez, Jose. 2015. "Defining and Measuring Consistency in Sentencing." In Exploring Sentencing Practice in England and Wales, edited by Julian Roberts. London: Palgrave Macmillan.

Pina-Sanchez, Jose, and Robin Linacre. 2013. "Sentence Consistency in England and Wales." British fournal of Criminology 53(6):1118-35. 
Player, Elaine, Julian Roberts, Jessica Jacobson, Mike Hough, and James Robottom. 2010. "Remanded in Custody: An Analysis of Recent Trends in England and Wales." Howard Fournal of Criminal fustice 49:231-61.

Radzinowicz, Leon, and Roger Hood. 1979. "Judicial Discretion and Sentencing Standards: Victorian Attempts to Solve a Perennial Problem." University of Pennsylvania Law Review 17(5):1288-1349.

Raine, John, and Eileen Dunstan. 2009. "How Well Do Sentencing Guidelines Work? Equity, Proportionality and Consistency in the Determination of Fine Levels in the Magistrates' Courts of England and Wales." Howard Fournal 48 (1):13-36.

Ramsay, Peter. 2013. The Insecurity State. Oxford: Oxford University Press. Renaud, Gilles. 2004. Speaking to Sentence. Toronto: Carswell.

Roberts, Julian. 2004. The Virtual Prison. Cambridge: Cambridge University Press.

2011. "Sentencing Guidelines and Judicial Discretion: Evolution of the Duty of Courts to Comply in England and Wales." British 7ournal of Criminology 51:997-1013.

2012. "Points of Departure: Reflections on Sentencing outside the Definitive Guidelines Ranges." Criminal Law Review (6):439-48.

- 2013. "Sentencing Patterns in England and Wales: Findings from the Crown Court Sentencing Survey." In Sentencing Guidelines: Exploring the English Model, edited by Andrew Ashworth and Julian Roberts. Oxford: Oxford University Press.

- 2015. Exploring Sentencing Practice in England and Wales. London: Palgrave Macmillan.

Roberts, Julian, and Ben Bradford. 2015. "Sentence Reductions for a Guilty Plea: New Empirical Evidence from England and Wales.” Zournal of Empirical Leoal Studies 12(2):187-210.

Roberts, Julian, and Oren Gazal-Ayal. 2013. "Sentencing Reform in Israel: An Analysis of the Statutory Reforms of 2012." Israel Law Review 46:455-79.

Roberts, Julian, and Mike Hough. 2011. "Custody or Community? Exploring the Boundaries of Public Punitiveness in England and Wales." Criminology and Criminal 7ustice 11:185-202.

- 2015. "Empirical Sentencing Research: Options and Opportunities." In Exploring Sentencing Practice in England and Wales, edited by Julian Roberts. London: Palgrave Macmillan.

Roberts, Julian, Mike Hough, and Andrew Ashworth. 2011. "Personal Mitigation, Public Opinion and Sentencing Guidelines in England and Wales." Criminal Law Review (7):524-30.

Roberts, Julian, Mike Hough, Jonathan Jackson, and Monica M. Gerber. 2012. "Public Attitudes toward the Lay Magistracy and the Sentencing Council Guidelines: The Effects of Information on Opinion." British 7ournal of Criminology 52(6):1072-91.

Roberts, Julian, and Keir Irwin-Rogers. 2015. "Sentencing Practices and Trends in England and Wales, 1999-2013." In Exploring Sentencing Practice in England and Wales, edited by Julian Roberts. London: Palgrave Macmillan. 
Roberts, Julian, and Wei Pei. 2016. "Structuring Judicial Discretion in China: Exploring the 2014 Sentencing Guidelines." Criminal Law Forum 27(1):3-33.

Roberts, Julian, and Jose Pina-Sanchez. 2014. "Previous Convictions at Sentencing: Exploring Empirical Trends in the Crown Court." Criminal Law Review (8):575-88.

Roberts, Julian, and Anne Rafferty. 2011. "Sentencing Guidelines in England and Wales: Exploring the New Format." Criminal Law Review (9):680-89.

Sentencing Commission Working Group. 2008. Sentencing Guidelines in England and Wales: An Evolutionary Approach. London: SCWG.

Sentencing Council of England and Wales. 2011. Assault: Definitive Guideline. http://sentencingcouncil.judiciary.gov.uk/.

. 2014a. Fraud, Bribery and Money Laundering Offenses: Definitive Guideline. http://sentencingcouncil.judiciary.gov.uk/.

. 2014b. Robbery Guideline Resource Assessment. London: Sentencing Council of England and Wales.

.2015a. Assessing the Impact and Implementation of the Sentencing Council's Assault: Definitive Guideline. http://www.sentencingcouncil.org.uk/wp-content /uploads/Assault-assessment-synthesis-report.pdf.

- 2015b. Crown Court Sentencing Survey: 2014. London: Sentencing Council. https://www.sentencingcouncil.org.uk/publications/item/crown-court -sentencing-survey-annual-publication-2014-full-report-2/.

Sentencing Guidelines Council. 2004. New Sentences: Criminal fustice Act 2003. London: Sentencing Guidelines Council.

- 2007. Sentence Reductions for a Guilty Plea: Definitive Guideline. London: Sentencing Guidelines Council.

- 2009. Overarching Principles: Sentencing Youtbs. London: Sentencing Guidelines Council.

Sparks, R. F. 1971. "The Use of Suspended Sentences." Criminal Law Review, 384-96.

Spencer, H. 1860. "What Is to Be Done with Our Criminals?" British Quarterly Review (July):42-70.

Thomas, David. 1970. Principles of Sentencing. London: Heinemann.

Tonry, Michael. 2004. Punishment and Politics: Evidence and Emulation in the Making of English Crime Control Policy. Cullompton, UK: Willan.

von Hirsch, Andrew. 1976. Doing Fustice. New York: Hill \& Wang.

von Hirsch, Andrew, and Julian Roberts. 2004. "Legislating Sentencing Principles: The Provisions of the Criminal Justice Act 2003 Relating to Sentencing Purposes and the Role of Previous Convictions." Criminal Law Review (August):639-52.

Wacquant, Loic. 2009. Punishing the Poor. Durham, NC: Duke University Press.

Walmsley, Roy. 2013. World Prison Population List. 10th ed. London: International Centre for Prison Studies.

Wasik, Martin. 2014. "Sentencing: The Last Ten Years." Criminal Law Review (7):477-91.

Young, Warren, and Claire Browning. 2008. "New Zealand's Sentencing Council." Criminal Law Review (4):287-98. 
Young, Warren, and Andrea King. 2013. "The Origins and Evolution of Sentencing Guidelines: A Comparison of England and Wales and New Zealand." In Sentencing Guidelines: Exploring the English Model, edited by Andrew Ashworth and Julian Roberts. Oxford: Oxford University Press.

Youth Justice Board. 2014. Annual Report, 2013-2014. London: Youth Justice Board. 